\title{
THE APPLGATLON OF NUGLEAR
}

\section{BNEReY TO AGRIGULTURE}

Triennial Report

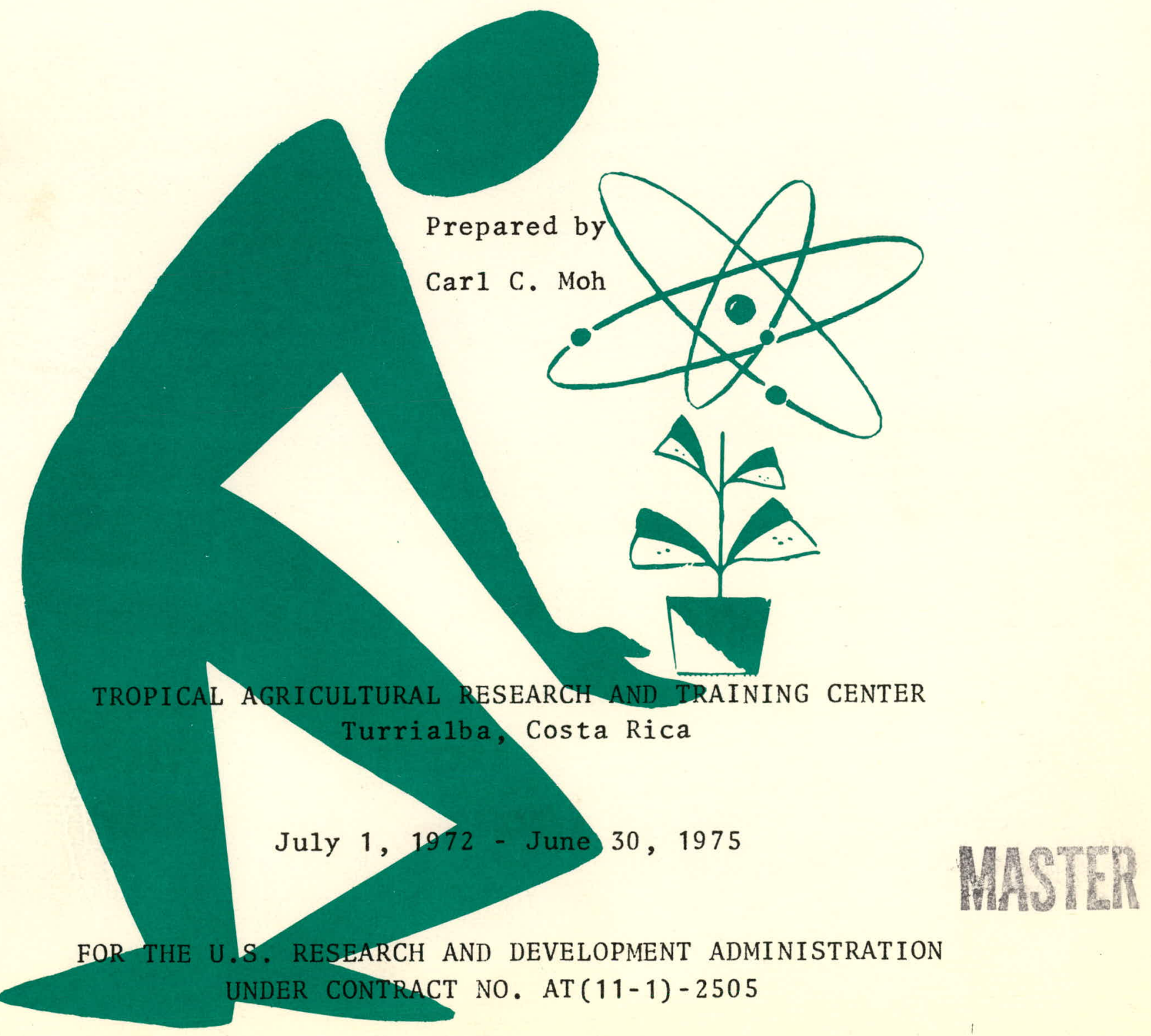




\section{DISCLAIMER}

This report was prepared as an account of work sponsored by an agency of the United States Government. Neither the United States Government nor any agency Thereof, nor any of their employees, makes any warranty, express or implied, or assumes any legal liability or responsibility for the accuracy, completeness, or usefulness of any information, apparatus, product, or process disclosed, or represents that its use would not infringe privately owned rights. Reference herein to any specific commercial product, process, or service by trade name, trademark, manufacturer, or otherwise does not necessarily constitute or imply its endorsement, recommendation, or favoring by the United States Government or any agency thereof. The views and opinions of authors expressed herein do not necessarily state or reflect those of the United States Government or any agency thereof. 


\section{DISCLAIMER}

Portions of this document may be illegible in electronic image products. Images are produced from the best available original document. 
$\mathrm{COO}-2505-02$

\section{THE APPLICATION OF NUCLEAR}

ENERGY TO AGRICULTURE

Triennial Report

Prepared by

Car1 C. Moh

This report was prepared as an account of work sponsored by the United States Government. Neither the United States nor the United States Energy Research and Development Administration, nor any of their employees, nor any of their contractors, subcontractors, or their employees, makes any warranty, express or implied, or assumes any legal liability or responsibility for the accuracy, completeness or usefulness of any information, apparatus, product or process disclosed, or represents that its use would not infringe privately owned rights.

TROPICAL AGRICULTURAL RESEARCH AND TRAINING CENTER Turrialba, Costa Rica

July 1, 1972 - June 30,1975

FOR THE U.S. RESEARCH AND DEVELOPMENT ADMINISTRATION UNDER CONTRACT No. AT $(11-1)-2505$ 
I. RESEARCH ACCOMPLISHMENTS

A. INDUCED MUTATIONS AND PLANT IMPROVEMENT

1. Mutation Breeding in Cassava (Manihot esculenta)

a. Methods of inducing mutations in cassava 3

b. Selection of early maturity mutant 5

c. Induction of vigorous erect mutant 8

d. Breeding for low cyanogenic glucoside content

1) Screening technique: the Guignard test 12

2) Screening the cultivars in the cassava collection

3) Screening the $R_{1}$ and $R_{2}$ progenies from pollen irradiation

4) Somatic mutation induction

5) Anther culture

2. Mutation Breeding in Beans (Phaseolus vulgaris)

a. Number of black bean varieties subjected to seed-coat color change by the induced mutation method

b. Distribution of the white bean mutant, NEP-2

c. Agronomic characteristics and the food value of the NEP-2 mutant

d. Breeding for high protein content 28

1) Screening method 28

2) Protein content of the seed-coat color mutants

B. BIOCHEMICAL AND PHYSIOLOGICAL PROPERTIES OF CASSAVA 35

1. Photosynthetic Metabolism of the Cassava Leaf 36

a. Materials and methods 36

b. Results and discussion 37

2. Translocations of Radioactive Carbon after
Assimilation of $14 \mathrm{CO}_{2}$

a. Materials and methods 40

1) Incubation chamber 40

2) Conditions of $14 \mathrm{CO}_{2}$ fixation experiment 40

3) Description of plant material 41

b. Results and discussion 42

3. Metabolic fate of translocated photosynthetic carbon 
a. Materials and methods 45

1) Preparation of enzyme extracts 45

2) Determination of enzymatic activity 46

b. Sucrose reactions catalyzed by cassava root enzymes

c. Fructose reactions catalyzed by cassava root enzymes

d. Glucose-1-phosphate reactions in the cassava root

e. Catalytic activity of cassava starch granules from cassava root

f. Enzymatic activities present in the starchy tissue of the cassava seed stalk

4. Summary of Biochemical Characteristics of Cassava

C. COLLECTION OF RAINEALL FOR FALLOUT ANALYSIS

II. PLANS FOR THE CONTINUATION OF OBJECTIVES AND POSSIBLE NEW OBJECTIVES IN CONSIDERATION OF PAST RESULTS

A. Induced Mutations and Plant Improvement

1. Cassava (Manihot esculenta)

2. The common bean (

B. Photosynthetic Efficiency and Plant Productivity

III. GRADUATE STUDENTS TRAINED, AND. DEGREE GRANTED

IV. BIBLIOGRAPHY

62

V. OPINION AS TO THE PRESENT STATE OF KNOWLEDGE IN THIS

AREA OF RESEARCH, ITS SIGNIFICANCE IN THE FIELD OF

BIOLOGY AND MEDICINE AND NEEDED FUTURE INVESTIGATIONS

64

A. Mutation Breeding and Plant Improvement 64

B. Biochemical and Physiological Properties of Cassava 66

VI. THE PRESENT DIVISION OF FEDERAL SUPPORT FOR THE PROGRAM 
Professional staff

Carl C. Moh, Ph.D. USA

Oscar Hidalgo, Ph.D. 1

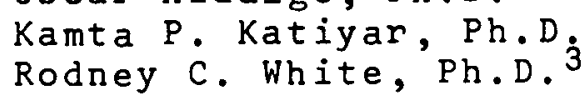

Juan Jose Alan, M.S. 4

Non-professional Staff

Lucia Lopez

Emma Roda

Luis Carlos Araya 5

Alvaro Castillo6

Ronald Leon?

Luis Mora

Rafael Mora 8

Carlos Solano
Nicaragua

India

USA

Costa Rica
Cytogeneticist, Head of Program

Insect Pathologist

Entomologist

Plant Physiologist

Jr. Cytogeneticist

1. Position terminated, September 1973.

2. Position terminated, April 1973.

3. Joined Program, March 1974.

4. Left Program, for advanced study, June 1973.

5. Joined Program, October 1974.

6. Resigned November 1972 .

7. Joined Program, March 1973. Resigned March 1974.

8. Retired, September 1973.

9. Replaced Castillo, December 1972. Position terminated, February 1973. Rejoined Program, replacing Leon, April 1974. 


\section{RESEARCH ACCOMPLISHMENTS}

\section{A. INDUCED MUTATIONS AND PLANT IMPROVEMENT}

(C. C. Moh)

In recent years, because of the problem of world-wide food shortage, much emphasis has been given to the increase of crop production. This can be accomplished by growing improved crop strains and/or by employing efficient cultivation systems. In the tropics, root crops and pulses (food legumes) are the principal energy and protein source in the human daily diets. While the yields of the small grains (wheat and rice) have been improved significantly in some areas, the production of root crops and pulses has remained at a static level. Moreover, more than 50 percent of the farms in the American tropics are small, less than 5 hectares. An intensive cultivation system is necessary in order to maximize the crop production. The USAID has recently supported research on multiple cropping systems in the American tropics.

The success of the multiple cropping system depends not only on the types of crops adequately selected for a growing area, but also on the phenotypes of the plants which will give a maximum productivity and an efficient operation. Thus, plants with the following agronomic characteristics are beneficial for production in the system: (1) vigorous or fast growing ability for the vegetatively propagated crops, (2) short life cycle or early maturity for the seed producing crops, ( 3 ) erect or compact type of growth, and (4) high productivity or high nutritional value. 
During the past years, research on plant improvement employing induced mutation method was carried out in our program. The objectives have been to induce certain agronomic characters of the crops that are more advantageous for production, or to improve the food quality for human consumption. Some desirable mutants, such as the white seed mutant of bean and the compact mutant of coffee, have been multiplied and are being distributed to many countries, while the other mutants, such as the erect mutant of cassava and high protein of beans need to be purified and further field tested. Moreover, work on inducing a mutant in cassava low in cyanogenic glucoside content has not been completed and needs more irradiated progenies for further screening. A more detailed description of the research during the past years is presented below.

1. Mutation breeding in cassava (Manihot esculenta) In the tropics, the root crops serve as an important staple food as do the small grains in the temperate zones. Among the several root crops, cassava is of utmost importance. It has been estimated that about 200-300 million people in the tropics use cassava as a staple food (Nestel, 1973). Because of its great potential in root production (10-30 tons of fresh roots per acre), cassava is probably one of the few food crops which can make a prominent contribution to the world food supply. The significance of cassava in the world food supply has been reviewed in an USAID report (AID Contract No. csd/2497, 1972). 
Although cassava has a high yielding capacity, it has its agronomic weaknesses. One is the presence of cyanogenic glucosides which release hydrocyanic acid ( $H C N$ ) when hydrolyzed. Some cultivars yield more than $200 \mathrm{mg}$ of $\mathrm{HCN}$ per $100 \mathrm{~g}$ of root tissues. The other weakness is that the maturity period for the roots is relatively long. Normally, some cultivars take 10 to 12 months for roots to mature after planting, but some others take from one to two years. Moreover, the plant morphology of cassava varies greatly from cultivar to cultivar. Many have a wide branching growth pattern interfering with the growth of other crops which is undesirable in a multiple cropping system. Thus, acyanogenesis, earliness and better form of growth are the breeding objectives in cassava.

\section{a. Methods of inducing mutations in cassava On theoretical grounds, seeds, stem cuttings,} and pollen can be irradiated for inducing mutations. However, certain plant materials of cassava are inefficient and impractical for use in mutation induction. A discussion of the feasibility of inducing mutations in different plant materials and the experimental results obtained are presented below.

1) Seed irradiation. By irradiating seeds, the mutations induced in the $R_{1}$ plants usually appear in a chimeric form. Since cassava has a pronounced protogynous flowering habit, it is difficult to self-pollinate the chimeric sectors to bring out the recessive mutations. In order to isolate the induced recessive mutations, it is necessary to (1) purify the 
chimeric sectors, and (b) synchronize the flowering time of the male and female flowers by planting the purified chimeric cuttings at different time intervals for self-pollination. Considering these procedures, seed irradiation is obviously time consuming and may not be an efficient means for mutation induction in cassava.

2) Cutting irradiation. Irradiation of stem cuttings may be a convenient way to induce somatic mutations in. cassava. In the experiments presented in a previous report, we found that a dose of $5 \mathrm{kr}$ of gamma radiation is lethal to the cuttings. A dose range of 3 to $4 \mathrm{kr}$ was generally used for inducing somatic mutations in cassava.

The somatic mutation rates induced by stem irradiation have been studied in a number of cassava cultivars. Most of the cultivars produced rather low mutation frequencies; only very few had a higher mutation rate. These results were attributed to the fact that the common cassava cultivars are polyploids and that there is a large difference in the degree of genetic heterozygosity among the cultivars (see 1969-1972 triennial report to AEC, $C 00-3217-05)$.

3) Pollen irradiation. Mature pollen of cassava were collected at anthesis and irradiated with 2 to $6 \mathrm{kr}$ of gamma rays. The irradiated pollen were immediately pollinated to the pistillate flowers. When the fruits matured, the seeds were collected and stored for 2 to 3 months. We found that this storage period greatly improved the seed germination in cassava. 
In the preliminary experiments we used cultivar No. 68 in our collection as the plant material because this cultivar is free of cytological abnormalities in meiosis and has normal fertile pollen.

The mutation frequencies in the $R_{1}$ generation obtained from pollen irradiation are presented in Table 1. At relatively low radiation doses of 2 to $4 \mathrm{kr}$, the mutation rates induced were appreciable. When higher doses of 5 to 6 $\mathrm{kr}$ were used, an $R_{1}$ mutation rate could be obtained as high as 50. percent. Moreover, the induced characters appeared homogeneously in the $R_{1}$ plants without chimeric formation.

Most induced mutations found in the $R_{1}$ generation were morphological. More commonly, they were changes in leaf size, leaf shape, plant form, and growth habit. The induced mutated characters in the $R_{1}$ generation were a permanent change rather than a temporary physiological disturbance. Stem cuttings from the $R_{1}$ plants were propagated in the field and those with the mutated characters in the $R_{1}$ remained identical in the subsequent vegetatively propagated generations. We postulate that the majority of these $R_{1}$ mutants were the results of induced chromosomal aberrations, especially deletions, since many $R_{1}$ mutants were associated with sterility.

b. Selection of early maturity mutant Along the Pacific coast of Central America, there is a distinctive alternation of a wet and a dry season in the year. The cassava only grows during the wet season and 
Table 1. Morphological mutation rates in the $\mathrm{R}_{1}$ generation induced by pollen irradiation in cassava (Cultivar No. 68 )

\begin{tabular}{cccc}
$\begin{array}{c}\text { Radiation dose } \\
(\mathrm{kr})\end{array}$ & $\begin{array}{r}\text { Total } \mathrm{R}_{1} \\
\text { plants }\end{array}$ & $\frac{\mathrm{R}_{1} \text { morphological mutations }}{\mathrm{No}}$ \\
\hline $\begin{array}{c}\text { Control (selfing) } \\
2\end{array}$ & 168 & $0 *$ & 0 \\
4 & 48 & 10 & 20.8 \\
5 & 39 & 10 & 25.6 \\
6 & 58 & 29 & 50.0 \\
& 65 & 33 & .50 .8
\end{tabular}

* Only one type of chlorophyll mutation, yellow-green, was found among the selfed progenies, but no morphological mutations similar to those radiation-induced were found.

passes the dry period by shedding its leaves. Thus, a cassava plant usually takes two years to mature. With this agricultural weakness, cassava can hardly compete with other crops with a shorter life cycle. A cassava cultivar maturing in 6 to 7 months instead of the normal 10 to 12 months, should be of advantage in many cassava growing areas.

In the experiments using the pollen irradiation method for inducing mutations, we found a number of vigorous progenies in the $R_{1}$ generation. Since cassava is normally vegetatively propagated, these mutants can be used directly for field evaluation without further genetic purification. Four selections of the $R_{1}$ mutant and four other cultivars were planted at the end of May, 1973. and harvested at the end of 
November of the same year. This growth period covered exactly six months during the rainy season. At the end of the growth period, about 100 plants from each of the eight selected lines were harvested to study the root production. The results are presented in Table 2.

Table 2. Root production of the selected mutant lines and the cultivars of cassava grown on the Pacific coast of Costa Rica from May 31 to November 30,1973

Lines or cultivar

No. of plants studied
Average root weight (kilograms/plant)
M 7 2-7.2-1

M72-7.2-2

M72-7.2-3

M72-7.2-13

$\mathrm{F}_{1} \# 56 \times \# 68$

\#56

\#68

Turrialba Guacima
98

98

99

96

100

98

103

103
1.98

2.81

2.48

$2.37 \%$

2.62

2.93

$2.68 \%$

2.53

* Selected for future field trials, because of the good root size as well as other good plant characters.

As can be seen from the results, some lines (M72-

7.2-2 and \#56) appeared to have higher root yields in the field trial. But they were discarded as undesirable lines for the following reasons: (1) Although the total root yields were higher due to profuse root production, the diameter of the roots had not reached edible size in 6 months and usually the roots 
were fibrous. (2) The soils in this coastal area are highly clayey and hard in the dry season. These cassava strains producing long roots make harvesting extremely difficult and tedious. Usually the roots are damaged during harvesting. We selected two strains, M72-7.2-13 and \#68, for further testing. These two lines produced an average of 5 to 6 lb of fresh roots in this 6-month period. The roots are relatively short and easy to harvest. In addition the line, M72-7.2-13, has good cooking and eating qualities. Fig. 1 shows the cassava field trial in the Pacific coast area and the roots of the mutant line, M72-7.2-13, which are of good edible size in a 6-month growth period.

c. Induction of vigorous erect mutant

By irradiating the pollen of a cassava cultivar (No. 68) with a range of gamma radiation doses from 2. to $10 \mathrm{kr}$, a total of $760 R_{1}$ progenies was obtained and the 197 selfed progenies without irradiation were used as a control. The $R_{1}$ seeds were germinated in the greenhouse and then were transplanted to the nursery. The cuttings from the mature $R_{1}$ plants were grown in the field for evaluation. A vigorous erect mutant was isolated from a population of the progenies whose parents were irradiated with $4 \mathrm{kr}$ of gamma rays (Fig. 2 ).

The height of this mutant from ground level to the position of branching was $147 \mathrm{~cm}$ as compared with $85 \mathrm{~cm}$ for the control (Table 3 ). This vigorous erect growth habit is a desirable character for the multiple cropping system. 


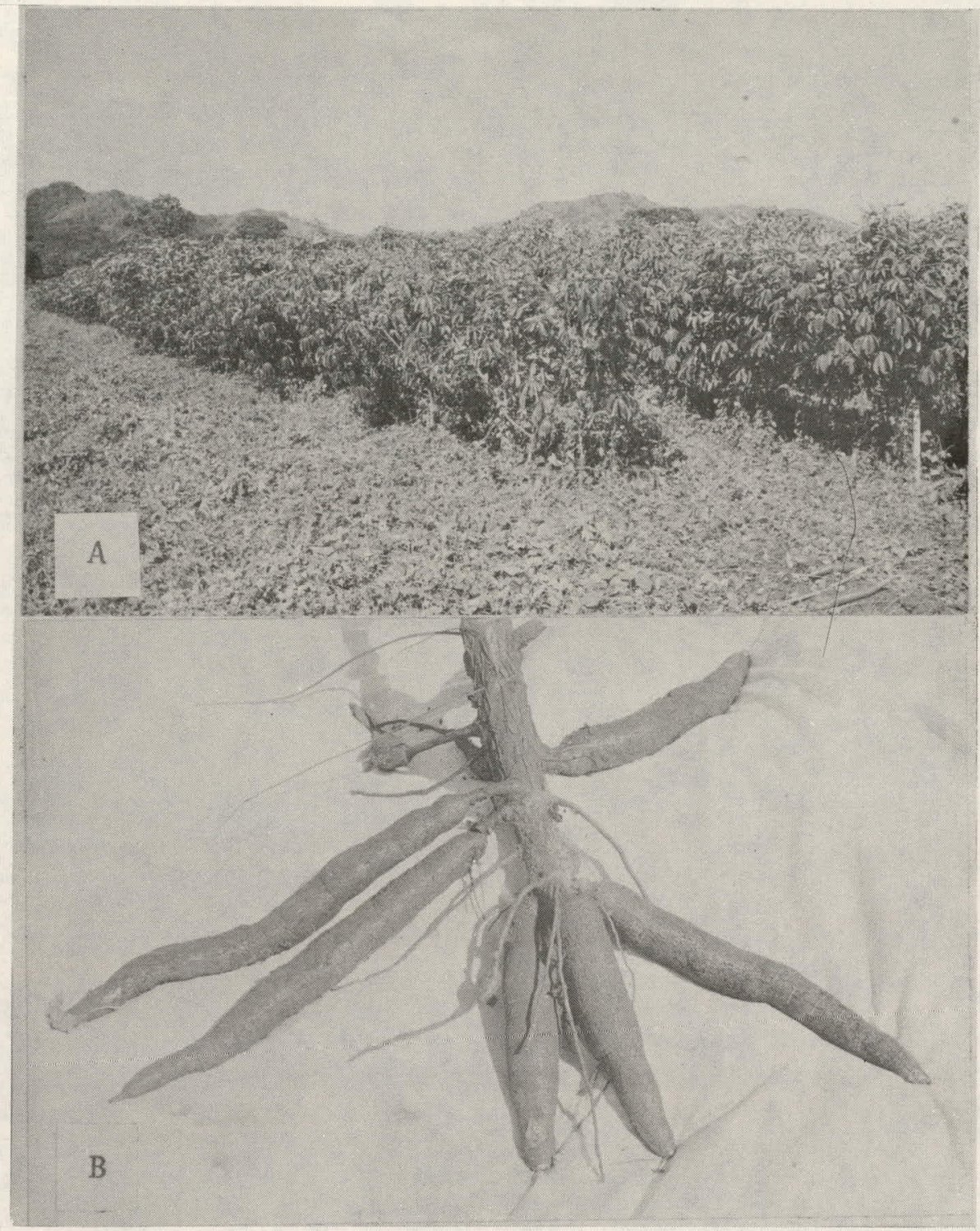

Fig. 1. A. Field trial of cassava mutants on the Pacific coast of Costa Rica. The cassava plants were 6-months old at the end of the rainy season. B. Cassava roots from a mutant plant, M72-7.2-13, showing the size suitable for eating. The roots of this plant weighed more than $10 \mathrm{lb}$. 


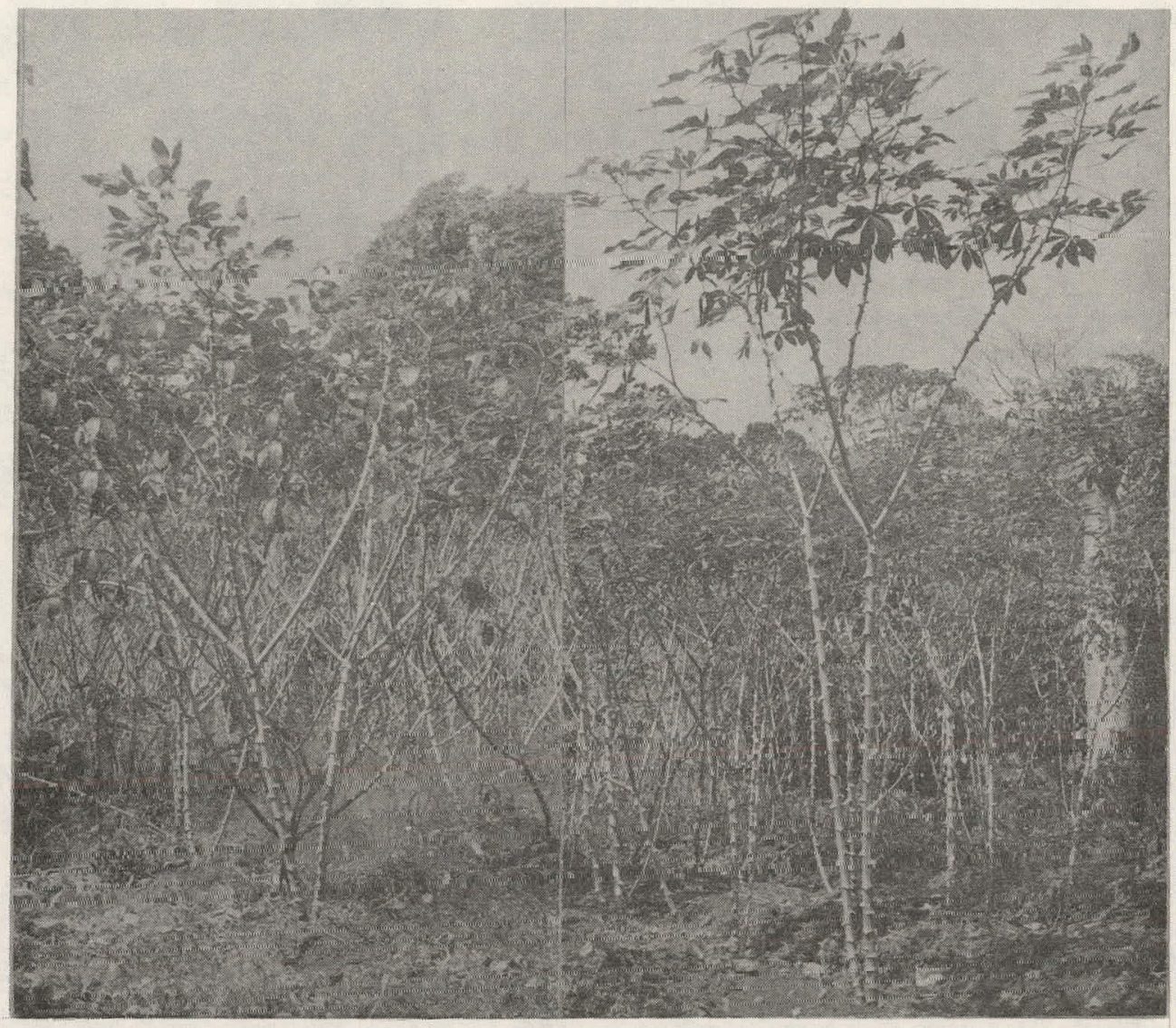

Fig. 2. Left, normal growth pattern of cassava plant (cultivar No. 68), with somewhat prostrate branching habit. Right, a vigorous erect mutant among the $R_{1}$ progenies from pollen irradiation. 
Essentially, this mutant gives less interference with other crops and greatly facilitates the field operation. This mutant is being propagated in quantity and a study of the root production is also being carried out.

Table 3. Height of the normal plants, $R_{1}$ progenies from pollen irradiation $(4 \mathrm{kr})$, and the selected vigorous erect mutant

Plant

Plant height from ground level to branching position $(\mathrm{cm})$

Normal (ck) 85.6

$R_{1} \underset{(4 \mathrm{kr})}{\operatorname{progeny}}$ from pollen irradiation 82.5

The selected mutant 147.0

d. Breeding for low cyanogenic glucoside content The poisonous nature of cassava due to hydrocyanic glucosides has long been known. In recent years, concern has arisen as to the probable, chronic toxic effects on humans using cassava as a staple food. Speculation has arisen that amblyopia in West Africa may be a manifestation of chronic cassava poisoning. Recent medical studies in a cassava-eating area of Nigeria showed that the patients with the tropical ataxic syndrome had a high thiocyanate level in the plasma (cf. Montgomery, 1969). This medical evidence heightens the possibility that long term consumption of cassava as a main dietary material could give rise to chronic disease in man. 
The fundamental solution of this problem is to cultivate the cassava free of hydrocyanic glucosides. However, cassava cultivars completely free of these glucosides have not been found. Thus, induced mutation may be an alternative method for the breeding.

1) Screening technique: the Guignard test

To look for a cultivar which has extremely low or no content of the glucosides, it is necessary to have a simple and efficient technique to screen a large population of cassava plants. While quantitative methods for determining the HCN released from the glucosides give more accurate results, the methods are usually tedious and time consuming. We found that the qualitative method, the Guignard test, is more practicable for the screening purpose.

The Guignard test has been described in a number of publications (e.g., Methods of Analysis, A.O.A.C., 1970). Because of the extreme simplicity of this method, it would be convenient to describe it briefly here. Sodium picrate paper is prepared by dipping the filter paper (Whatman chromatography paper No. 1 works well) into $1 \%$ picric acid, drying the paper, and then dipping it into $10 \%$ sodium carbonate and drying it again. The test plant tissue is finely chopped and 1-2 $g$ of this sample are placed in a test tube. A few drops of chloroform are added to the sample and a moist strip of the sodium picrate paper is inserted in the tube which is then tightly stoppered. The paper gradually turns orange, then 
brick red or dark red. The reaction can be seen within half an hour under ordinary laboratory conditions, but we score the results from 3 to 4 hours. The rapidity of change in color of the paper depends upon the amount of free HCN released from the glucosides. It is said that this test can detect $5 \mathrm{mg}$ of $\mathrm{HCN}$ per $100 \mathrm{~g}$ of the sample (Montgomery, 1969). Since we are interested in the cassava cultivars with extremely low or no $H C N$ content, this method can be used for primary screening.

We have used this method to test a number of plant species in the family Euphorbiaceae to which cassava belongs and a number of tropical root crops, to see if this method is efficient to detect the presence or absence of $\mathrm{HCN}$ in these plants. Table 4 presents the reactions of the leaf or root tissues to the Guignard test. All the Manihot species in our collection and Hevea (rubber) showed a positive reaction; all the tested root crops except cassava showed a negative reaction. These results demonstrated that this test is reliable.

In order to determine what part of a cassava plant can best be used for the assay, the root, and the leaf were used for the testing. The middle section of a root was taken, and the outer cork layer (phellem) and the inner layer (cortex) of the peel, the core (xylem) and the central pith (primary $x y-$ lem) of the section were separated.' The test was run in duplicate. The results are presentedin Table 5 and demonstrated in Fig. 3 . 
Table 4. Reaction of Guignard test in several plant species of Euphorbiaceae family and tropical root crops

Plant

Tissue

Reaction of

Species of Euphorbiaceae family

Manihot glaziovii

Manihot $\frac{\text { grahami }}{\text { Manihot }}$

Manihot $\frac{\text { multiflora }}{\text { Manihot }}$

Hevea brasiliensis

Acalypha hispida

Euphorbia cotinifolia

Jatropha curcas

Ricinus communis

tested Guignard test

Tropical root crops

Manihot esculenta

Arracacia xanthorryza

Colocasia esculenta

Ipomoea batatas

Xanthosoma violaceum

$\begin{array}{ll}\text { leaf } & + \\ \text { leaf } & + \\ \text { leaf } & + \\ \text { leaf } & + \\ \text { leaf } & - \\ \text { leaf } & - \\ \text { leaf } & -\end{array}$

Table 5. Results of the Guignard test on the roots and leaves of 95 cassava cultivars

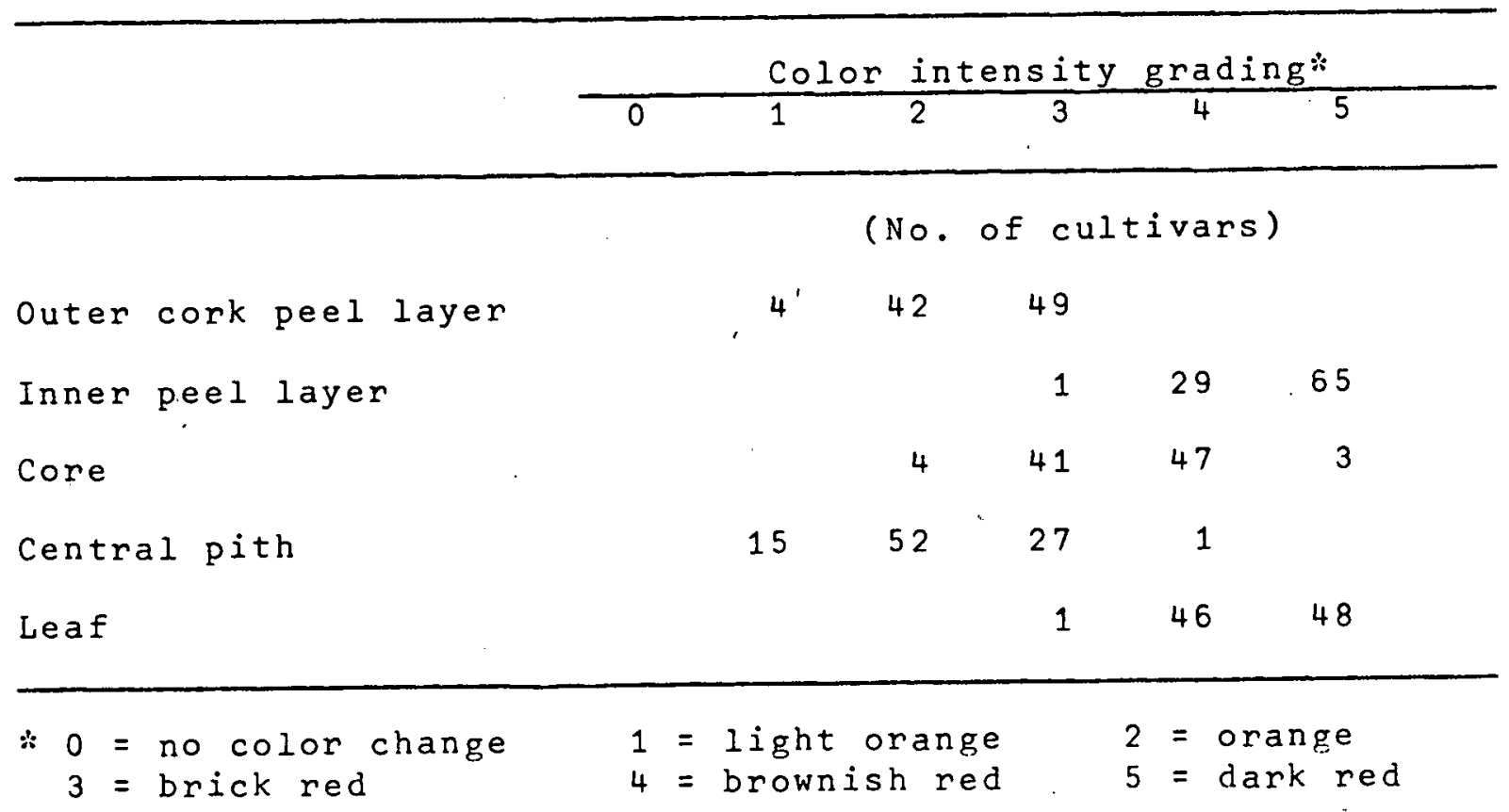




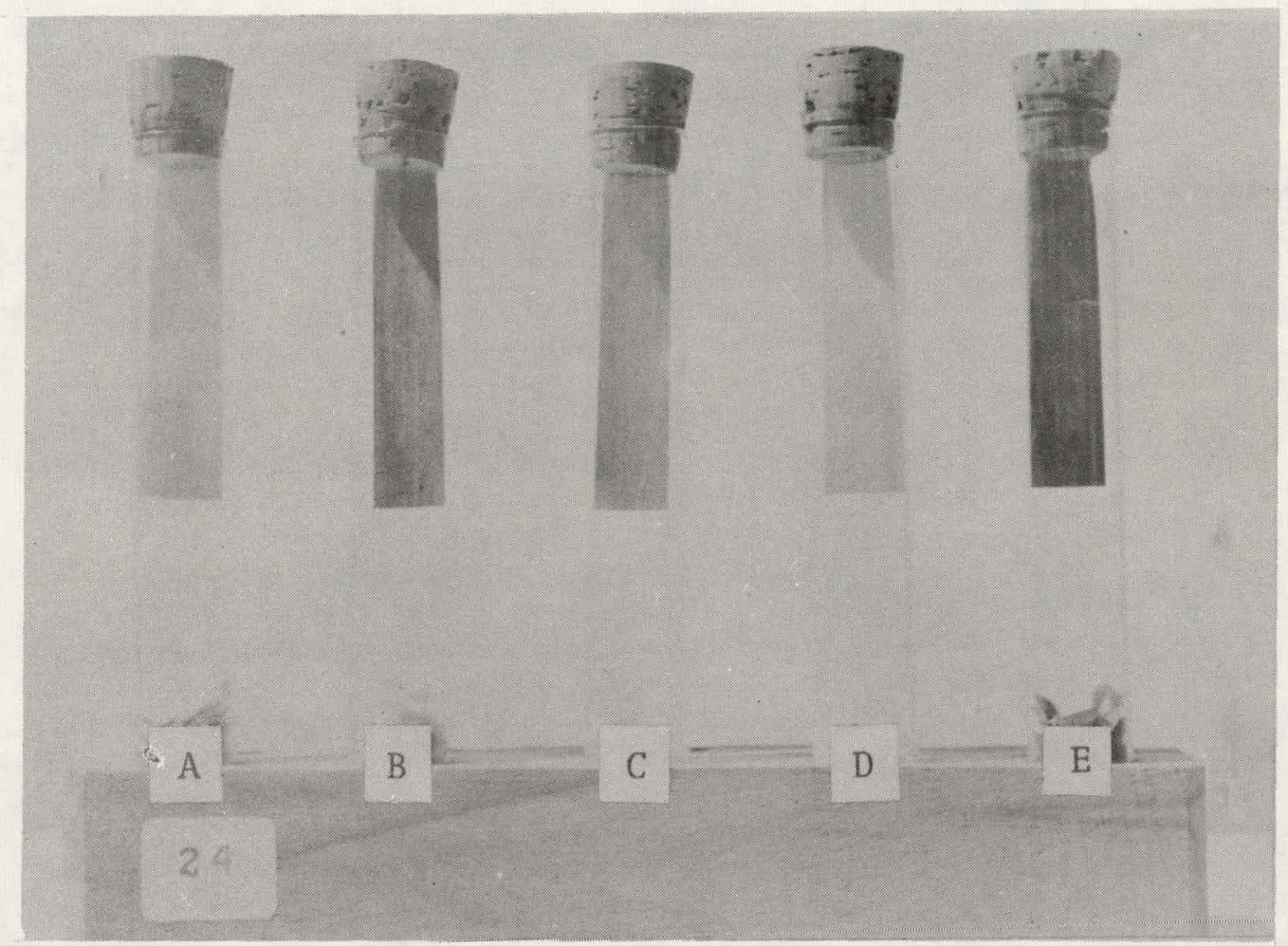

Fig. 3. Reaction to Guignard test of various cassava tissues. The color intensity on the filter paper in the test tube shows the relative amount of $\mathrm{HCN}$ released from the plant tissue.

A. Outer cork layer of the root.

B. Inner peel of the root.

C. Core of the root.

D. Central pith of the root.

E. Leaves. 
It showed that the leaves and the inner peel layer have the highest concentration of $\mathrm{HCN}$; the core (edible portion) has the second highest, and the outer cork layer of the peel and the central pith have the lowest:

Theoreticaliy, using the leaves as testing material should be very efficient, since the leaves permit an early screening in a plant life cycle. Table 6 presents the screening results of cassava leaves from more than $2.000 R_{1}$ and $\bar{R}_{2}$ progenies from pollen irradiation. Although most of the

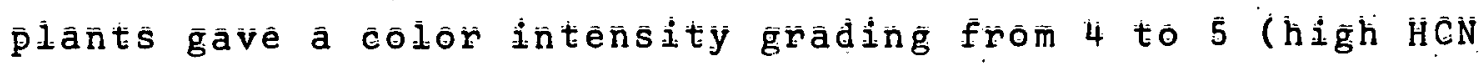

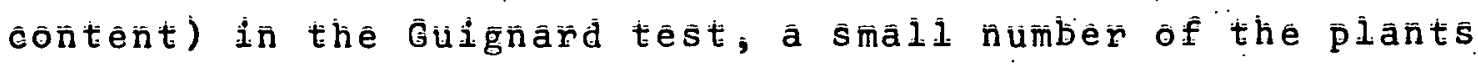
gave a reading below 3 . These supposedly low HCN plants have been tested further either by using another leaf of the same plant or its root, the test results showed that these plants belonged to the high HCN content categories. This indicates that using a leaf as a test material could give a spurious gram

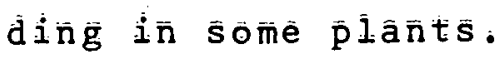

Similariy, the corres of the root (edible portion) of the $R_{1}$ and $R_{2}$ progenies were used as a test object. The results showed that they gave a broader fluctuation in $H C N$ grading than the leaves.

As indicated in Table 5 , the peel of a cassava root has the highest concentration of cyanogenic glucosides. Tests showed that the peels have given a consistent and reliable result. The peels are now being used for the screening of $\mathrm{HCN}$ content in all our experiments. 
Table 6. Results of the Guignard test for HCN content in the leaf of the $R_{1}$ plants and the $R_{2}$ selfed progenies of cassava from pollen irradiation

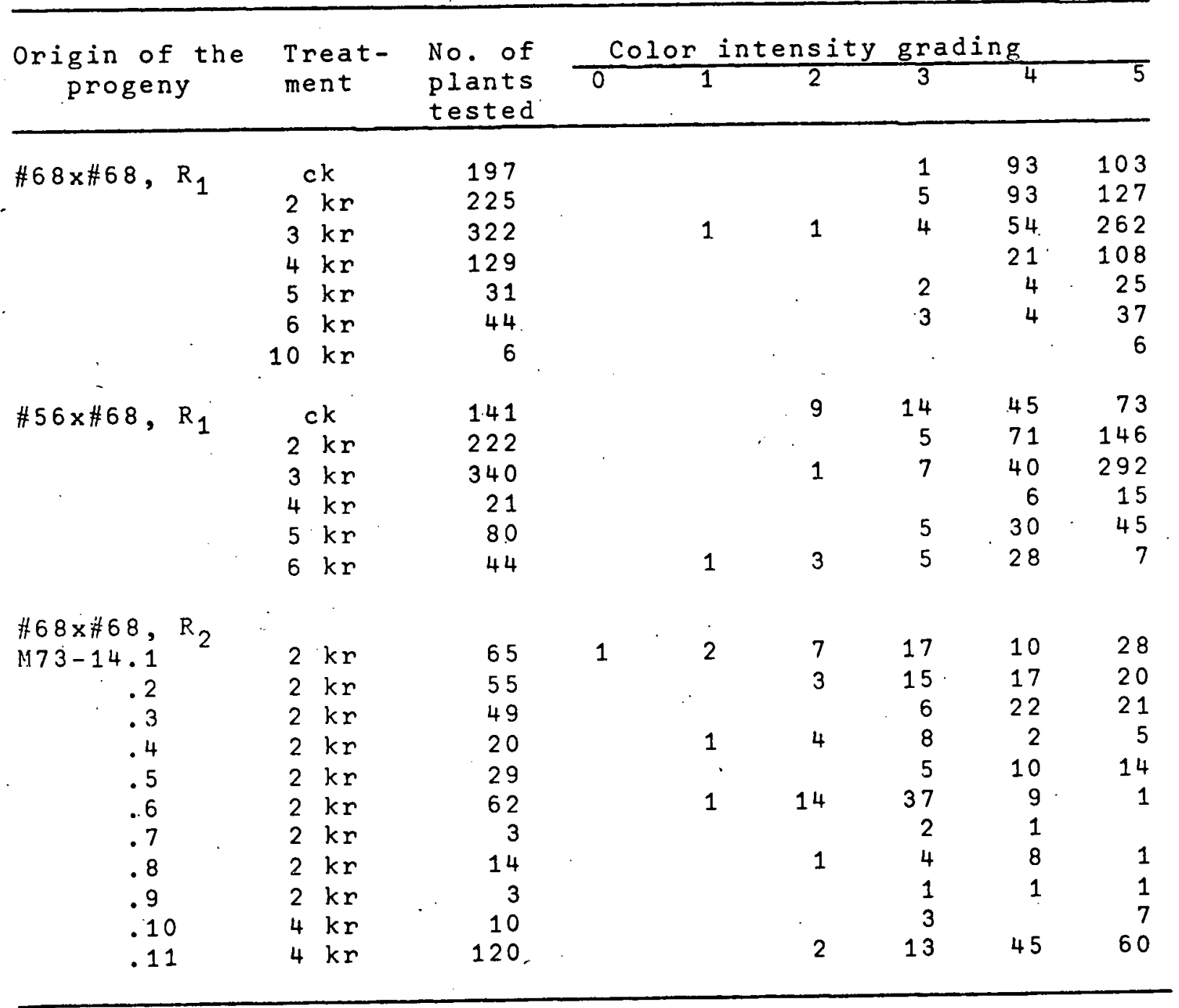

2) Screening the cultivars in the cassava collection

In our cassava coliection, there are more than 100 cultivars collected from different areas of central and South America. By using the peels of mature cassava roots, they were screened for $H C N$ content (Table 7). All the cultivars 
had a high $\mathrm{HCN}$ grading of 4 to 5 , suggesting that a cultivar with a low content of cyanogenic glucosides is not present in the cassava collection.

Table 7. Results of the Guignard test for HCN content in the peel of the root of the cassava cultivars in the collection No. of cultivars
tested
Color intensity grading

$\begin{array}{lllll} & & & \\ 0 & 1 & 3 & 4 & 5\end{array}$

3) Screening the $R_{1}$ and $R_{2}$ progenies from pollen irradiation

By using pollen irradiation method, we have obtained a large population of $R_{1}$ plants and $R_{2}$ selfed progenies. The peels of these plants were used for screening; and the results are presented in Table 8 . Since the use of the peel in the Guignard test is a rigid method for detecting $H C N$, the plants with relatively low $\mathrm{HCN}$ grading ( 3 or lower) are being selected for further testing. This screening study has not been completed; however, a few plants with a low $\mathrm{HCN}$ content have been found in the test.

4) Somatic mutation induction

The radiosensitivity of cassava shoot apex is known. Previous study has shown that a dose of $5 \mathrm{kr}$ of gamma radiation severely inhibits the growth of the shoot apex. 
Table 8. Results of the Guignard test for HCN content in the peel of cassava root of $R_{1}$ and $R_{2}$ progenies from pollen irradiation

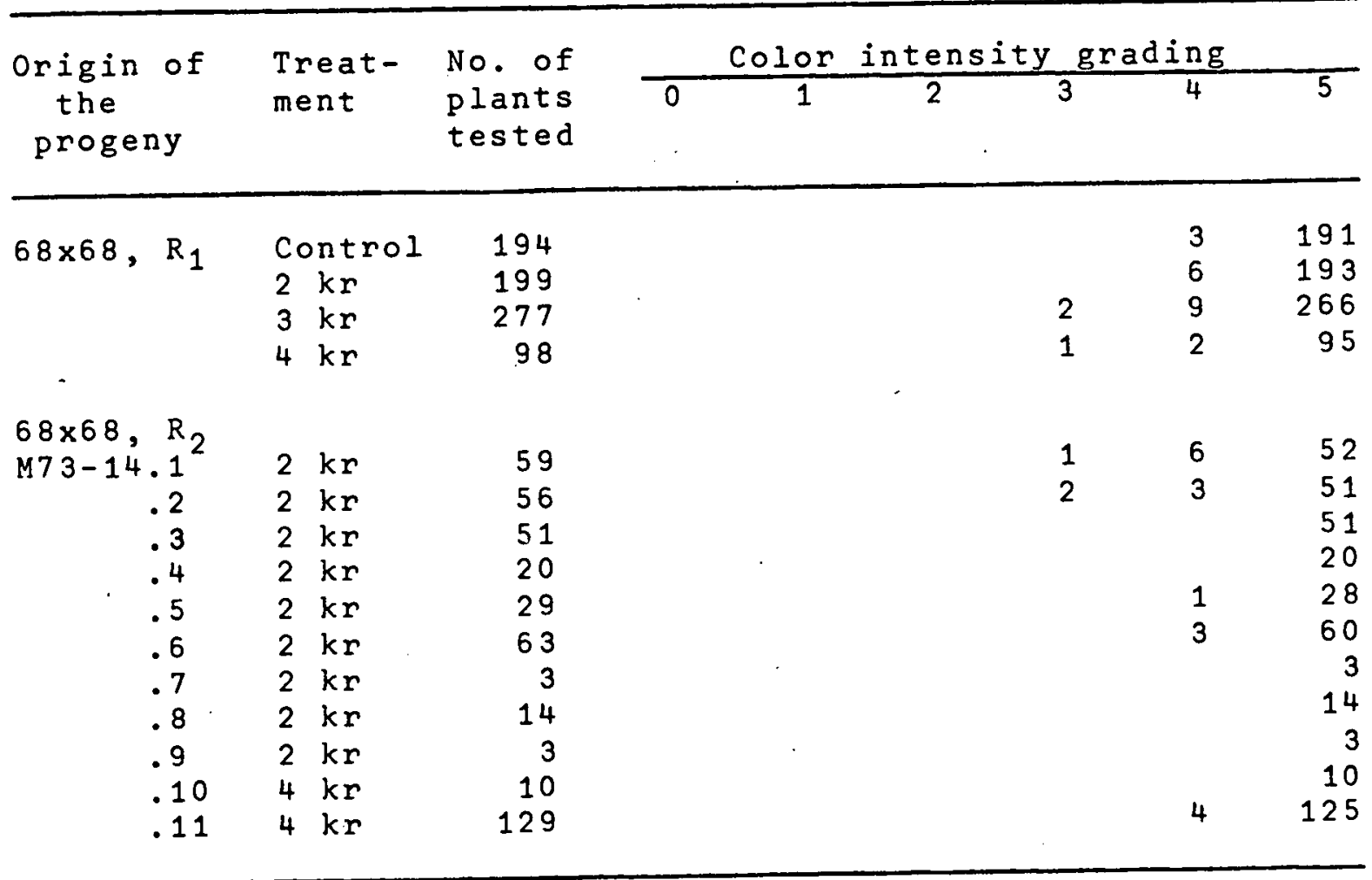

For inducing somatic mutations, a dose of $4 \mathrm{kr}$ is about the maximum that the shoot apex can tolerate. This year, more than 700 stem cuttings from two cultivars (No. 49 and No. 89) were irradiated with $4 \mathrm{kr}$. These irradiated materials will be propagated in the second vegetative generation $\left(V_{2}\right)$ for purifying the induced chimeras. Screening for low HCN mutants will follow.

\section{5) Anther culture}

In recent years, much interest has arisen in the induction and utilization of haploids in plant breeding. In vegetatively propagated crops, the haploid breeding method 
may have a significant value. Once an haploid is obtained, the haploid somatic tissue can be kept indefinitely and a large quantity of this haploid material can be propagated with relative ease for experimental uses. In the case of cassava, since many existing cultivated forms at present are probably the derivatives of natural hybrids, the induction of "haploid" (or plant with gametic chromosome number) would give an immediate manifestation of genetic characters for selection. Moreover, "haploid" $t$ issues are more efficient for inducing somatic mutation, usually giving rise to a higher mutation rate.

One of the methods for obtaining haploids is to use anther culture technique. In recent years, this method has been successful in a number of plant species, but the nutritional requirement of the culture medium and the cultural conditions usually varied from species to species. During the past year, more than 20 different or modified culture media have been tested in our laboratory, but many failed to cause the anthers of cassava to grow. In this report, we present the experimental method and the medium which have enabled cassava anthers to produce a callus thus far.

Cassava cultivar No. 68 was selected as the experimental plant material since this cultivar has no pollen sterility as tested by the iodine-potassium iodide solution. Cuttings were grown in a nursery until inflorescence began to appear. The inflorescences were then bagged with very fine nylon screen cloth to avoid insect damage to flower buds. When 
the female flowers of an inflorescence fully opened, a certain size of male flowers (before opening) was selected for experimental use. The best size of the male flowers for anther growth is 4 to $5 \mathrm{~mm}$ in length. Too old or too young flowers gave poor results.

The selected male flowers were sterilized in $70 \%$ alcohol for $30 \mathrm{sec}$, followed by immersion in clorox solution for 60 sec. and then rinsed with sterilized water. The ten anthers of a male flower were dissected and each was inoculated. in a test tube which contained about $10 \mathrm{ml}$ of sterilized culture medium.

The culture medium was essentially the same as that of Murashige and Skoog's (1962) with modification in growth regulators. The composition of the culture medium is as follows:

\section{$\underline{\mathrm{mg} / \mathrm{L}}$}

$\mathrm{NH}_{4} \mathrm{NO}_{3}$

$\mathrm{KNO}_{3}$

$\mathrm{CaCl}_{2} \cdot 2 \mathrm{H}_{2} \mathrm{O}$

$\mathrm{MgSO}_{4} \cdot 7 \mathrm{H}_{2} \mathrm{O}$

$\mathrm{KH}_{2} \mathrm{PO}_{4}$

$\mathrm{Fe}-\mathrm{Na}_{2}-\mathrm{EDTA}$

$\mathrm{H}_{3} \mathrm{BO}_{3}$

$\mathrm{MnSO}_{4} \cdot 4 \mathrm{H}_{2} \mathrm{O}$

$\mathrm{ZnSO} 4^{\circ} \cdot 4 \mathrm{H}_{2}^{2}$

$\mathrm{KI}$

$\mathrm{Na}_{2} \mathrm{MOO}_{4} \cdot 2 \mathrm{H}_{2} \mathrm{O}$

$\mathrm{CuSO}_{4} \cdot 5 \mathrm{H}_{2} \mathrm{O}$

$\mathrm{CoCl}_{2} \cdot 6 \mathrm{H}_{2} \mathrm{O}$
1650

1900

440

370

170

*

6.2

22.3

8.6

0.83

0.25

0.025

0.025
$2,4-D$

IAA

Kinetin

Glycine

Myo-Inositol

Thiamine-HCl

Niacin

Pyridoxin

Coconut milk $10 \%$ by volume Sucrose

Agar $\underline{\mathrm{mg} / \mathrm{L}}$

4

1

0.2

2.0

100.0

1.0

0.5

0.5
$8 \mathrm{~g} / \mathrm{L}$

* $5 \mathrm{ml} / \mathrm{L}$ of a stock solution composed of $5.57 \mathrm{~g} \mathrm{FeSO}_{4} \cdot 7 \mathrm{H}_{2} \mathrm{O}$ and $7.45 \mathrm{~g} \mathrm{Na}_{2}$. EDTA per 1 liter of $\mathrm{H}_{2} \mathrm{O}$. 
The medium was adjusted to a $\mathrm{pH}$ of 5.8 with $0.1 \mathrm{~N} \mathrm{NaOH}$, and autoclaved at $15 \mathrm{psi}$ for $15 \mathrm{~min}$.

The anthers were incubated in an incubator in the dark at $28^{\circ} \mathrm{C}$. After 2 to 4 weeks, the pollen grains as well as the anther were enlarged if the anther survived. Otherwise the anther began to shrivel. After 4 to 6 weeks, the anther wall was ruptured and the callus from the anther began to appear. Usually, the growth of the callus was very slow. Larger calluses can be transferred to a similar medium for further development. It is not certain now whether the callus was developed from the pollen grain or from the other somatic tissue of the anther. An examination of the chromosome number of the callus may help to identify the source of origin.

Usually the filament attaching to the anther of a stamen also developed a callus. The growth of the filament callus was so rapid that it easily outgrew the anther callus in a test tube. An early separation of these two types of callus was necessary.

Occasionally, the filament calluses developed roots (Fig. 4) when transferred to a culture medium devoid of 2,4-D but with a higher level of kinetin $(4 \mathrm{mg} / \mathrm{l})$. Shoot development has not been found. Probably shoot regeneration may need other growth substances in the medium as described by Kartha, et al. (1974).

References

A literature review and research recommendations on cassava. AID Contract No. csd/2497. University of Georgia. 1972. 


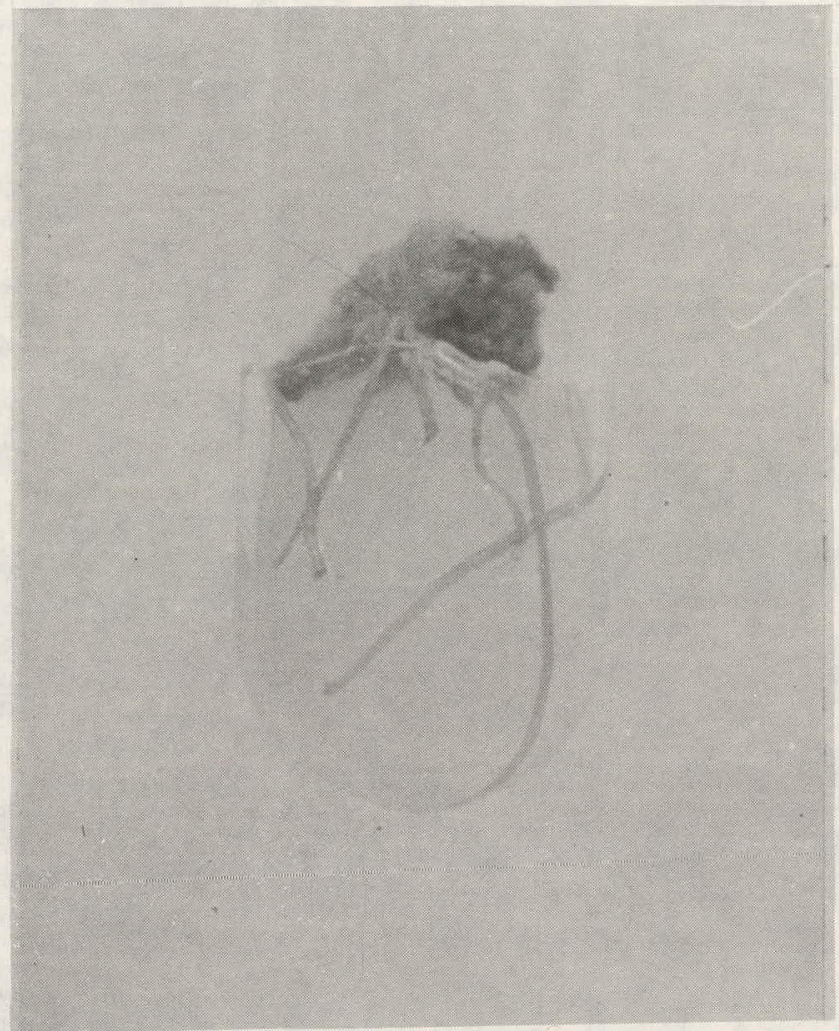

Fig. 4. Roots differentiated from the callus of anther filament of cassava. 
Kartha, K. K., O. L. Gamborg, F. Constabel and J. P. Shyluk. 1974. Regeneration of cassava plants from apical meristems. Plant science Letters 2:107-113.

Methods of analysis. Association of official analytical chemists. Horwitz, W.; ed. 11th Edition, 1960. p. 438.

Montgomery, R. D. 1969. "Cyanogens", in Toxic Constituents of Plant Foodstuffs, Leiner, I.E., ed. Academic Press, New York.

Murashige, T. and F. Skoog. 1962. A revised medium for rapid growth and bioassays with tobacco tissue culture. Physiol. Plant. 15:473-497.

Nestel, B. 1973. Foreword. In Chronic Cassava Toxicity. Ed. by $B$. Nestel and R. MacInt $\overline{y r}$. International Development Research Centre. Ottawa, Canada.

2. Mutation breeding in beans (Phaseolus vulgaris)

a. Number of black bean varieties subjected to seedcoat color change in the induced mutation method since the development of the induced mutation method for changing seed-coat colors in beans in our program (see 1969-. 1972 Triennial Report to AEC, C00-3217-05), students from South American countries have brought their local superior black varieties to our center with the objectives of: 1) learning the mutation technique in their training program, and 2 ) inducing the seed coat color mutants to fulfill their local needs. Up to the present date, 7 black varieties have been treated, and a total of 12 white mutants have been obtained, not including other seed-coat color mutants. Evidently, this induced mutation method is an efficient.one and can be applied to a wide variety of black beans for improving their seed-coat color. 
b. Distribution of the white bean mutant, NEP-2. Since the development of the white bean mutants through the induced mutation method, the seeds of a mutant line, NEP-2, have been propagated in great quantity. In cooperation with the Department of Tropical Crops and Soils at the Turrialba Center here, the seeds have been distributed to 33 institutions in 20 countries for further field trials or laboratory tests (Table 9).

Table 9. Countries and Institutions which have received the NEP-2 white bean mutant

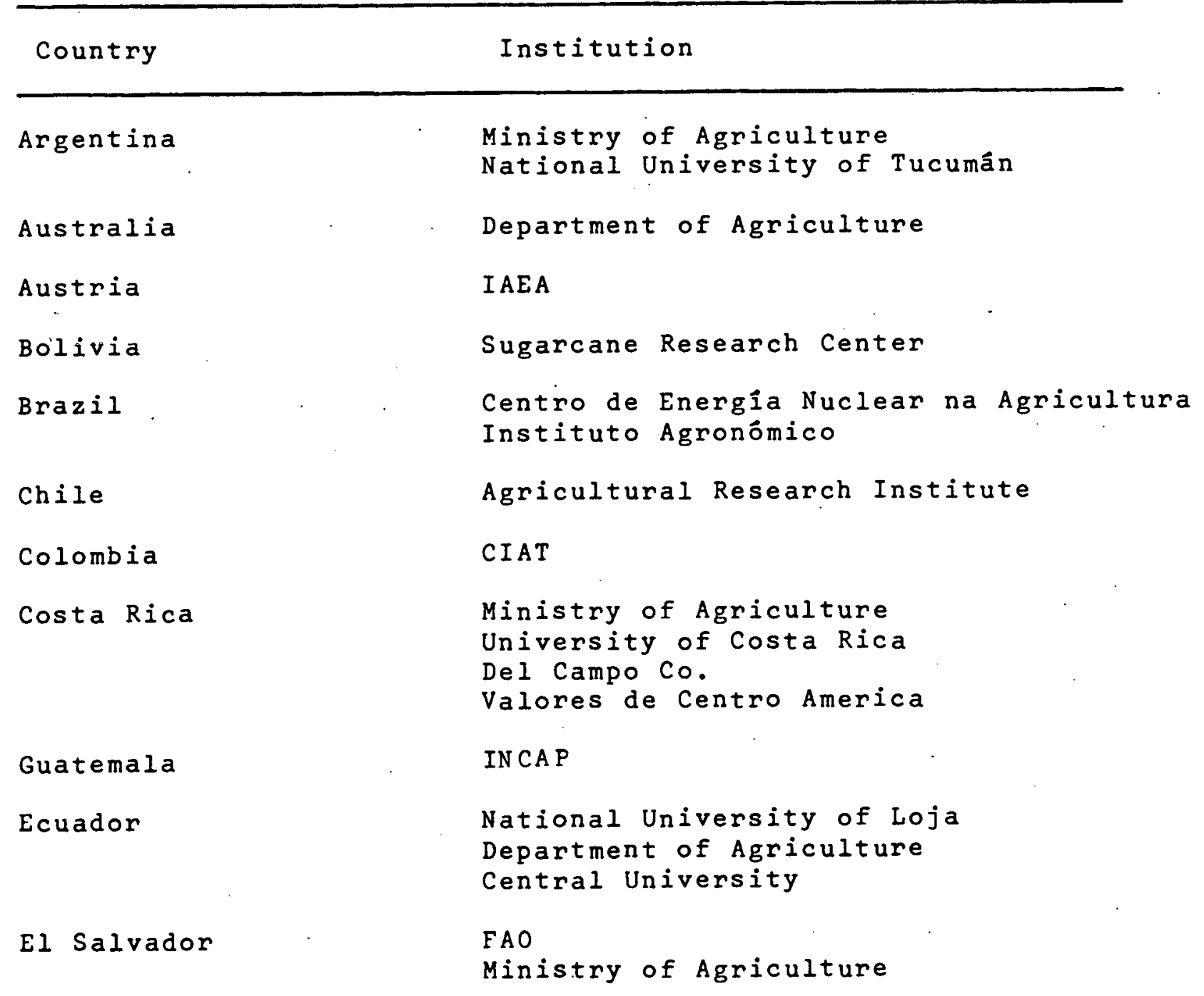


Table 9. Continued...

\begin{tabular}{|c|c|}
\hline Country & Institution \\
\hline Haiti & I ICA \\
\hline Jamaica & $\begin{array}{l}\text { Ministry of Agriculture } \\
\text { University of West Indies } \\
\text { Orange River Agricultural Station }\end{array}$ \\
\hline Malawi & University of Malawi \\
\hline Paraguay & National University of Asuncion \\
\hline Peru & $\begin{array}{l}\text { Regional Center of Agricultural Re- } \\
\text { search }\end{array}$ \\
\hline Portugal & H. J. Heinz Co. \\
\hline Trinidad and Tobago & Chaguaramas Agricultural Development \\
\hline Uganda & Makerere University \\
\hline USA & $\begin{array}{l}\text { USDA } \\
\text { University of Michigan } \\
\text { Cornell University } \\
\text { Federal Experiment Station, Puerto } \\
\quad \text { Rico }\end{array}$ \\
\hline
\end{tabular}

c. Agronomic characteristics and the food value of the NEP-2 mutant

Since the NEP-2 mutants have been sent to various parts of the world for a field trial or for laboratory tests, the results sent back so far indicate that the NEP-2 mutant has the following good agricultural characteristics.

1. Field trial carried out by Dr. C.L.A. Leakey in Makerere University, Uganda, indicated the NEP-2 mutant has exceeded in yield all other small white beans from several hundreds in their bean collection, and remained entirely free from rust. 
2. The field trial in Ecuador indicated that the NEP-2 mutant was one of the top producers among the 20 bean varieties tested. The field trial located in Loja County which is $1,750 \mathrm{~m}(5,740 \mathrm{ft})$ above sea level which is about the maximum altitude that beans can grow.

3. In a preliminary field trial of the bean mutants in Michigan State, NEP-2 appeared to be a very promising bean under their conditions, according to Dr. M. W. Adams.

4. Dr. M. W. Adams also informed us that the NEP-1 and NEP-2 mutants have a low percentage of stachyose, raffinose, and sucrose. These sugars are believed to be implicated in the flatulence problem in beans.

5. The rat feeding experiment of the NEP-2 white mutant and its black parent has been repeated by INCAP (Nutrition center of Central America). The NEP-2 beans induced twice the body weight gain in comparison with the black bean parent in 28 days. These results confirm the data obtained from the same laboratory a year before. Since the difference in protein content between these two lines is insignificant (although the NEP-2 mutant is slightly higher), the feeding results are difficult to explain at present. It may be due to a higher protein digestibility of the NEP-2 mutant.

6. According to Mr. David Coode of the H. J. Heinz Co. of England, NEP-2 has very good canning quality. Evidently, the NEP-2 bean was sent to England by Dr. Leakey for the quality test. 
Some institutes are using the NEP-2 mutant for hybridization to improve their local bean strains. More recently, a food company (Valores de Centro America) in Costa Rica, has requested 125 metric tons of NEP-2 beans per year for its dehydrated soups and other products.

d. Breeding for high protein content Because of the world-wide food shortage, improvement of agricultural food crops has been emphasized not only in quantity but also in quality. In the tropics, pulses or food legumes are a major source of proteins in many developing countries. While the production in wheat and rice has been improved significantly in recent years, the pulse yields have remained at a low level. The reason for this, no doubt, has been due to the lack of new high-yielding varieties or the lack of improved. technique for the improvement. Since the common bean is a principle staple food crop in the American tropics, the possibility is being explored of using induced mutation method for protein improvement in this crop.

\section{1) Screening method \\ Dr. Rodney White of our Nuclear Energy Program}

recently used a modified colorimetric method for determining the water soluble protein from bean seeds. The method is briefly described as follows.

Beans which have been dried in a $37^{\circ} \mathrm{C}$ oven are pulverized in a Wiley mill to pass through a U.S. standard 60 
mesh sieve. The powdered samples are subsequently kept at $40^{\circ} \mathrm{C}$ for at least 2 days in order to attain a uniform moisture content. Samples of $50 \mathrm{mg}$ are weighed and placed in test tubes to which $5 \mathrm{ml}$ of distilled water is added. The tubes are agitated vigorously, capped with parafilm, and stored in the cold for approximately 16 hours (overnight).

After warming to room temperature, the samples are assayed for protein content by a modification of the method of Bramhall et al. (1969). For this, 50 ul aliquots of well mixed solution are applied to $3 \times 3 \mathrm{~cm}$ squares of Whatman No. 1 filter paper with calibrated capillary tubes. Numerous samples can be applied to a single sheet of paper which has previously been marked into labeled squares with a soft pencil. The dry squares are cut apart and placed in cold $7.5 \%$ trichloroacetic acid in order to fix the proteins within the paper. The acid solution is next heated at $80^{\circ} \mathrm{C}$ for half an hour, then discarded and the papers washed with chloroform/ethanol ( $1 / 1$ vol) followed by chloroform. The dry papers are stained with naphthalene blueblack dye $(10 \mathrm{mg} / \mathrm{ml})$ at $50^{\circ}$ for 15 minutes. Excess dye is removed by rinsing several times with hot $7 \%$ acetic acid. After placing in individual tubes, $5 \mathrm{ml}$ of $0.05 \mathrm{~N} \mathrm{NaOH}$ is added and the dye released measured at $620 \mathrm{~nm}$. standard protein and paper blanks are treated together until the dye is released from the papers. The quantity of protein is calculated by direct reference to the internal standards. 
This extraction procedure and colorimetric method allows rapid determination of the water soluble proteins from the bean seeds (60-70\% of total protein). The reliability of this method for detecting different levels of protein in beans is shown by its comparison with the kjeldahl method (Table 10). It appears that the results obtained from these two methods showed a good correlation.

This colorimetric method can be used for preliminary screening. Once a plant with high protein level is located, it can always be reconfirmed by the kjeldahl method.

2) Protein content of the seed-coat color mutants By using the method described above as a screening technique for the protein content in the bean seeds, 14 seedcoat color mutants and their parent (S182N) were used for the preliminary study. The mutants were obtained from either the treatment of EMS, or the treatment of acute or chronic gamma rays. Table 11 presents the soluble protein content of different mutants.

Based on our current analytical results, the soluble protein content for the parental line of beans (S182N) varied from 12 to 16\%. A protein content should be considerably higher than $16 \%$ in this test in order to be considered as a significant increase in protein content. A mutant, Bayo-2, had a protein content of $24.4 \%$ as compared with its parent, $12.2 \%$. This mutant has been subjected to further analysis. 
Table 10. Protein percent in the seeds of different legumes as determined by the Kjeldahl and the colorimetric methods

\begin{tabular}{lcc}
\hline Legume species & Protein $\frac{q}{\text { Kjeldahl }}$ \\
method & $\begin{array}{c}\text { colorimetric } \\
\text { method }\end{array}$ \\
\hline
\end{tabular}

Phaseolus vulgaris

$\begin{array}{lll}\text { Catie } 1 & 22.8 & 12.2 \\ \text { Porrillo } & 23.0 & 12.3 \\ \text { S182N } & 20.1 & 12.0 \\ \text { S182N (autotetraploid) } & 34.5 & 23.3 \\ \text { NEP-6 } & 18.9 & 11.8 \\ \text { Bayo-1 } & 23.9 & 15.5 \\ \text { Bayo-2 } & 30.3 & 21.0 \\ \text { Bayo-7 } & 20.6 & 12.5 \\ \text { Bayo-15 } & 20.7 & 12.2 \\ \text { Bayo-21 } & 22.9 & 12.6\end{array}$

In order to confirm a higher protein content in the mutant Bayo-2, seeds of this mutant and its parent, which were harvested in different years, were used to repeat the protein content test. In addition, the micro kjeldahl method was also employed for total crude protein determination. The results are presented in Table 12 and show that the mutant had a consistently higher protein level than its parent in three analyses by two methods.

From an agronomic viewpoint, the Bayo-2 mutant has a number of defects. As shown in Fig. 5, the mutant is less vigorous as compared with its parent. The seeds are smaller in size and the seed-coats of some seeds are cracked. But the experimental results well demonstrate the possibility of using 
Table 11. Protein content in the seeds of the seed-coat color mutants of beans as determined by the colorimetric method

Material Mutagenic treatment*

Water soluble protein content $(q)$

Parent:

S182N (ck)

none

12.2

Mutant:

White-2

White-3

White -4

Bayo-1

Bayo-2

Bayo-3

Bayo -4

Bayo-14

Bayo-15

Bayo-16

Bayo-19

Bayo-20

Bayo-21

Bayo-22
EMS

acute gamma irradiation

EMS

EMS

EMS

EMS

acute gamma irradiation

chronic gamma irradiation

chronic gamma irradiation

acute gamma irradiation

chronic gamma irradiation

chronic gamma irradiation

chronic gamma irradiation

chronic gamma irradiation
12.0

12.6

11.6

13.5

24.4

12.5

12.1

13.7

11.9

16.3

13.1

13.9

12.7

14.9

* EMS: Ethyl methanesulfonate

Acute gamma irradiation: seed treatment with a massive dose at $2400 \mathrm{r}$ or less per minute.

Chronic gamma irradiation: plants grown in the gamma-field receiving $75 \mathrm{r}$ or less per day for the whole life cycle.

induced mutation method for protein improvement in agricultural plants.

References

The Application of Nuclear Energy to Agriculture. Triennial Report, 1969-1972, to the USAEC, COO-3217-05. 

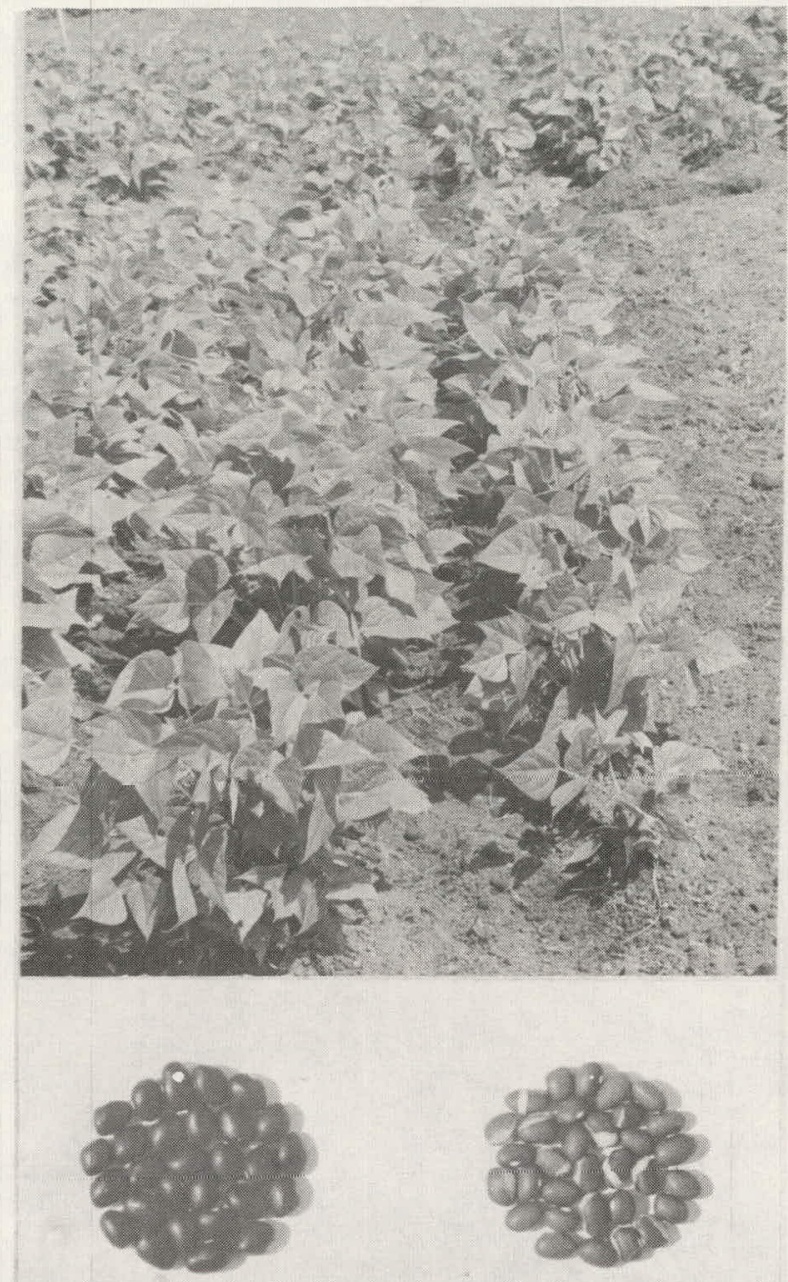

Fig. 5. Left, the original bean parent, S182N, producing black seeds. Right, the high protein mutant, Bayo-2, producing brown seeds. The mutant plants are less vigorous, and the seeds are smaller. The seed-coats of some seeds are cracked. 
Table 12. Protein content of the mutant Bayo-2 and its bean parent as determined by the micro kjeldahl method and the colorimetric method

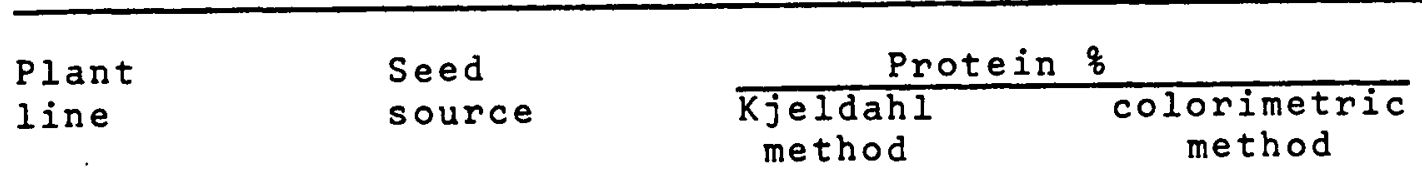

Parent:

$\begin{array}{llll}\mathrm{S} 182 \mathrm{~N}(\mathrm{ck}) & 1969 & 22.4 & 15.5 \\ & 1973 & 21.0 & 13.3 \\ & 1974 & 20.4 & 12.7\end{array}$

Mutant:

$\begin{array}{cccc}\text { Bayo-2 } & 1969 & 34.3 & 22.4^{\prime} \\ 1973 & 30.9 & 21.0 \\ 1974 & 30.7 & 20.4\end{array}$

Bramhall, S., N. Noack, M. Wu and J. R. Loewenberg. 1969. A simple colorimetric method for determination of protein. Analytical Biochemistry 31:146-148. 
B. BIOCHEMICAL AND PHYSIOLOGICAL PROPERTIES OF CASSAVA (Rodney C. White)

The potential of cassava, a plant common in the low land tropics, has only recently been recognized as a competitive commercial crop for the developing countries.: Although its genetic and agronomic properties are still mainly unexplored, yields of its roots grown under optimal conditions are reported. to be extremely high. The roots, due to their starch content, have a very high caloric value. Its productivity in terms of calories per unit land per unit time, in fact, has been reported to be higher than any other staple food crop (Coursey and Haynes, 1970). The high biological efficiency by which cassava stores solar energy in the form of starch suggests it to be a model system for the study of caloric productivity and its regulation. Net productivity and ultimately the yield, in terms of specialized plant parts, is due to an integration of numerous factors. A recent book (Zelitch, 1971) discusses each of these factors in detail.

The biochemical characteristics of cassava (photosynthesis, photorespiration, translocation, and starch synthesis) which are most directly related to plant productivity have not previously been studied. This research was undertaken to establish the basic photosynthetic metabolism and the means of distribution of the assimilated products into storage polymers by the cassava plant. 
1. Photosynthetic metabolism of the cassava leaf

a. Materials and methods

Manihot esculenta (cultivar \#68) plants were grown in an outdoor plot: Leaves from 2-3 month old plants were excised under water. The petioles were left in water and placed immediately in the light $(12,000 \mathrm{ft}-\mathrm{C})$. After 30 minutes in the light, one leaf was excised and inserted into a $60 \mathrm{ml}$ test tube which served as an incubation chamber. The light and temperature were kept constant throughout the labeling. experiment. The chamber was connected by a rubber hose to a vacuum pump via a "Carbosorb" $\mathrm{CO}_{2}$ trap. A piece of glass tubing extending to the bottom of the chamber was attached by a rubber tubing to a $5 \mathrm{ml}$ Warburg flask which served as a $\mathrm{CO}_{2}$ generation chamber. Also connected by tubing to the incubation chamber was a funnel through which boiling ethanol could be rapidly added.

By pulling a partial vacuum just prior to the experiment, ${ }^{14} \mathrm{CO}_{2}(90 \mu \mathrm{Ci})$ generated by acidifying $\mathrm{Ba}^{14} \mathrm{CO}_{3}$ in the closed Warburg flask could be released to the chamber instantaneously. After the desired time in the presence of $14 \mathrm{CO}_{2}$, the leaf was rapidly killed by adding boiling $80 \%$ ethanol.

After killing, the leaf was macerated for 2 minutes in high speed "Omni-Mixer". The extract was then filtered through a Millipore filter, washed once with $20 \mathrm{ml}$ of hot $80 \%$ ethanol and twice with $15 \mathrm{ml}$ of warm distilled water. The volume of the resulting solution was reduced to $5 \mathrm{ml}$ on a rotary vacuum evaporator at $35^{\circ} \mathrm{C}$. An aliquot of this extract was then applied 
to the origin of a paper chromatogram and run in both dimensions for 24 hours - phenol-water in the first and butanol-propionic acid-water in the second. An aliquot was also run on paper electrophoresis in $0.1 \mathrm{M}$ ammonium formate buffer, $\mathrm{pH} 3.5(40 \mathrm{~V} / \mathrm{cm}$ for 3 hours).

Radioactive compounds on paper were located by exposure to X-ray film. Each was then identified by co-chromatography and co-electrophoresis with authentic samples. Quantitative estimations were made by counting directly off paper with a manual operated $21 / 2$ inch brass gas-flow counting tube.

b. Results and discussion

After only 5 seconds in the presence of $90 \mu \mathrm{Ci}{ }^{14} \mathrm{CO}_{2}$, fifteen photosynthetic products were isolated. Sampes up to one minute fixation time were run and the percentage of total ${ }^{14} \mathrm{C}$ fixed in each metabolite is shown in Table 13. 3-Phosphoglyceric acid is the major early photosynthetic product and then progressively becomes a smaller percentage of the total. This is the labelling pattern expected for the first product of $\mathrm{CO}_{2}$ fixation (Bassham and Calvin, 1957). Thus it appears that the reductive pentose phosphate pathway $\left(\mathrm{C}_{3}\right.$ metabolism) is the major photosynthetic pathway in cassava. In order to substantiate the type of primary fixation process in cassava, its early photosynthetic products were directly compared with those of bean (a known $c_{3}$ plant) and sugarcane (a known $C_{4}$ plant). These results (Table 14) show sugarcane with $84 \%$ of its early products as malate and aspartate compared to $1 \%$ in 3 -phosphoglycerate. Bean 
Table 13. Early photosynthetic products of the cassava leaf (Results are expressed as the percentage of total radioactivity in individual compounds)

\begin{tabular}{|c|c|c|c|c|}
\hline \multirow[b]{2}{*}{ Product } & Time in & \multicolumn{3}{|c|}{ n presence of ${ }^{14} \mathrm{CO}_{2}$} \\
\hline & $5 \mathrm{sec}$. & 15 sec. & $30 \mathrm{sec}$ & $60 \mathrm{sec}$. \\
\hline Malate & 5.2 & 9.3 & 2.3 & 1.9 \\
\hline Glycolate & 14.5 & 49.7 & 41.9 & $19 \cdot 3$ \\
\hline Alanine & 2.5 & 5.9 & 8.2 & 8.3 \\
\hline Sucrose & 1.2 & 2.6 & 9.5 & $12 \cdot 1$ \\
\hline Serine, Glycine & 2.7 & 7.9 & 18.8 & 31.0 \\
\hline Aspartate & 1.4 & 5.6 & $<1.0$ & $<1.0$ \\
\hline Pentose monophosphates & 1.0 & 1.2 & 2.1 & 1.6 \\
\hline Hexose monophosphates & $7 . .7$ & 4.8 & 5.5 & 8.2 \\
\hline Sugar diphosphates & 1.3 & 1.0 & 1.0 & 1.0 \\
\hline Uridine diphosphoglucose & $<1.0$ & $<1.0$ & 1.6 & 2.5 \\
\hline 3-phosphoglyceric acid & 59.8 & 10.5 & 4.3 & 10.5 \\
\hline Phosphoenol pyruvic acid & 1.0 & $<1.0$ & $<1.0$ & $<1.0$ \\
\hline Dihydroxyacetone phosphate & $<1.0$ & $<1.0$ & $<1.0$ & $<1.0$ \\
\hline Citrate & $<1.0$ & $<1.0$ & $<1.0$ & $<1.0$ \\
\hline Glyceraldehye-3-phosphate & $<1.0$ & $<1.0$ & $<1.0$ & $<1.0$ \\
\hline
\end{tabular}

and cassava, on the other hand, have 428 and $60 \%$ as 3 -phosphoglycerate compared to $10 \%$ and $7 \%$ as malate and aspartate. This clearly demonstrates that cassava primarily hás a $c_{3}$ type metabolism. 
Table 14. Comparison of early photosynthetic products of sugarcane, bean, and cassava. (Results are expressed as the percentage of total radioactivity in individual compounds )

\begin{tabular}{lccc}
\hline Product & Cassava & Bean & Sugarcane \\
\hline Malate & 5.2 & 7.1 & 65.6 \\
Glycolate & 14.5 & 30.3 & 6.7 \\
Alanine & 2.5 & 3.0 & 6.8 \\
Sucrose & 1.2 & $<1.0$ & $<1.0$ \\
Aspartate & 1.4 & 3.1 & 16.9 \\
Serine, glycine & 2.7 & 5.2 & $<1.0$ \\
Hexose monophosphate & 7.7 & 3.6 & $<1.0$ \\
3 -phosphoglycerate & 59.8 & 42.3 & 1.2 \\
\hline
\end{tabular}

It is also evident that cassava has an active glycolate metabolism, as shown by the glycolate, serine, and glycine labelling patterns in these experiments. This suggests that a considerable amount of photorespiration is ocurring, which is typical of most $C_{3}$ plants and is usually thought to be a major factor in their low productivity. $c_{4}$ plants, however, carry on very little photorespiration and are highly productive (Bjorkman and Berry, 1974). Cassava is well documented as being a highly productive plant, perhaps even greater that sugarcane in terms of carbohydrate fixed.M-2.day-1. If this is the case, then cassava must either have a sufficiently high photosynthetic rate to make up for the loss of fixed carbon via photorespitation, or has 
a means of reducing the rate of photorespiration at the time of starch deposition.

2. Translocation of radioactive carbon after assimilation of $14 \mathrm{CO}_{2}$

a. Materials and methods

1) Incubation chamber

A plexiglas chamber, $11 \mathrm{in.} \mathrm{square} \mathrm{and} 4 \mathrm{in}$. deep, is attached via 2 in. air channels to a circulating fan enclosed in a galvanized metal chamber. This chamber has double walls through which water can be circulated for temperature control. The top half of the plexiglas chamber is removable and is held in place during experiments by 2 metal clasps on both sides of the chamber - a layer of soft rubber separates the 2 sections and makes a gas-tight seal when the clasps are tightened. Small holes through which glass tubes have been cemented are used for gassing the chamber. A $50 \mathrm{ml}$ beaker is attached to the bottom, directly below a porthole which is closed with a rubber serum stopper. The total volume of the system is 14 liters and when closed is completely gas tight.

2) Conditions of ${ }^{14} \mathrm{CO}_{2}$ fixation experiment Potted cassava plants grown outside for 2 to 3 months were used in these experiments. A plant was brought directly to the laboratory and one set of palmate leaves enclosed in the incubation chamber. A light intensity of $9000 \mathrm{ft}-\mathrm{C}$ was supplied by four 150 watt flood lamps held directly above the chamber. 
The light was cooled by filtering it through a circulating plexiglas water bath. The system was left open and air circulated for one hour. After this preincubation period, the system was closed and ${ }^{14} \mathrm{CO}_{2}$ released within the chamber. This was done by adding phosphoric acid to $3 \mathrm{mg}$ of $\mathrm{Ba}^{14} \mathrm{CO}_{3}(59.2$ $\mathrm{mCi} / \mathrm{mmole}$ ) contained in the $50 \mathrm{ml}$ beaker. The fixation of $14 \mathrm{CO}_{2}$ was allowed to proceed for $1 \mathrm{hr}$, then excess ${ }^{14} \mathrm{CO}_{2}$ was pumped from the chamber and passed through a "Carbosorb" $\mathrm{CO}_{2}$ trap. The leaf was removed from the chamber and various parts of the plant analysed for radioactivity. The analytical procedures for extracting and separating the radioactive compounds have been described in section $B .1$ of this report. For determination of total radioactivity, a small aliquot of the ethanol extract was applied to squares of filter paper, dried and quantitated on a gas-flow G.M. counter.

3) Description of plant material

The plant used for this experiment was $63 \mathrm{~cm}$ in height; the leaf selected for ${ }^{14} \mathrm{CO}_{2}$ fixation was $28 \mathrm{~cm}$ from the seed stalk. There were 7 sets of leaves + the meristem above the source leaf and 13 below. The following samples were taken as quickly as possible after completion of ${ }^{14} \mathrm{CO}_{2}$ fixation and killed by immersion in boiling $80 \%$ ethanol:

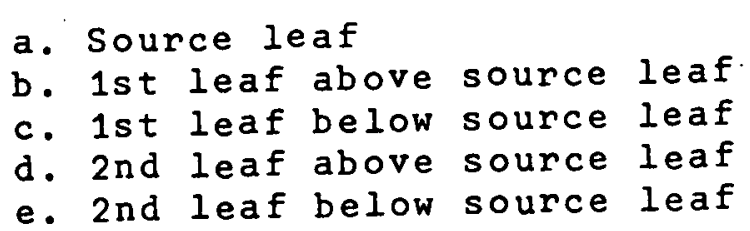

a. Source leaf

b. 1st leaf above source leaf

d. 2nd leaf above source leaf

e. 2nd leaf below source leaf $a_{1}$. Source petiole

$b_{1}$. 1st petiole above source

$c_{1}$. 1st petiole below source

$d_{1}$. 2nd petiole above source

$e_{1}$. 2nd petiole below source 


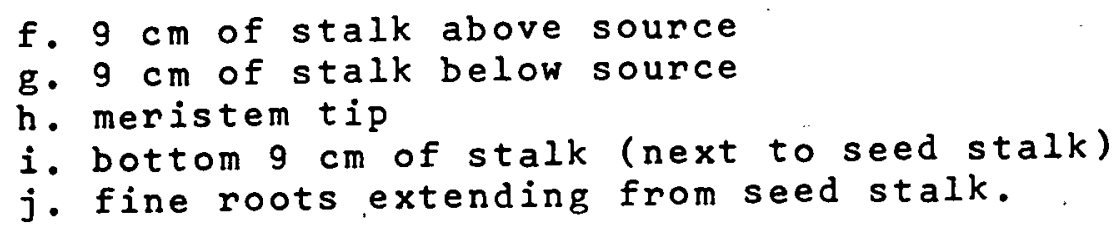

b. Results and discussion

The amount of total radioactivity measured in the various plant parts is described in Table 15: This data shows the direaction of flow of the photosynthate from the leaf to other parts of the plant in an actively photosynthetizing cassava plant. The translocated compounds are found mainly in those parts which are on the direct route to the root system. The samples with high radioactivity (source leaf, source petiole, and stalk directly below the source) were further analyzed by paper chromatography. sucrose was found to be the major end product of photosynthesis and essentially the only compound translocated (Table 16). Small amounts of the related oligosaccharides, raffinose and stachyose were also found to be translocated products.

When a potted bean plant (at pre-flowering stage) was labeled under similar conditions, a much wider distribution of translocated radioactivity was obtained (Table 17). A wide distribution of translocated sucrose has also been shown in the sunflower plant (Chopowick and Forward, 1974).

In cassava it appears that almost all of the photosynthate fixed is translocated directly to the root system even at the stage of rapid vegetative growth. This perhaps is typical of plants which produce storage roots or tubers. Other plants, however, appear to have a multidirectional flow of the translocated sucrose. 
Table 15. Distribution of radioactivity in the cassava plant after 1 hour assimilation of $14 \mathrm{CO}_{2}$ by one set of palmate leaves

Sample

Total radioactivity

$\mathrm{cpm}$

a

$\mathrm{a}_{1}$

$b_{1}$

$\mathrm{c}_{1}$

$\mathrm{d}_{1}$

e

$e^{1}$

$g$

h

$i$
$40,878,268$

$1,731,520$

4,620

5,126

2,016

2,586

1,876

2,032

1,513

1,724

6,192

464,684

8,960

19,188

2,884

3. Metabolic fate of translocated photosynthetic carbon

As shown in the previous section, sucrose is the photosynthetic product which is translocated to the seed stalk and ultimately to the roots of cassava. The seed stalk from which the cassava plant develops appears to not only function as the source of growth materials, but also to serve as a storage organ in the early stages of development. From the first month through the third, there is a soft-fleshy layer of tissue formed just under the bark of the seed stalk which has a high starch content. After three months, this tissue becomes woody and no longer contains starch. In order to better understand the fate of sucrose metabolism in the seed stalk and the root the following work with "in vitro" enzyme preparations was carried out. 
Table 16. Distribution of radioactivity in the source leaf, source petiole, and the stalk just below the source leaf after 1 hour assimilation of $14 \mathrm{CO}_{2}$

\begin{tabular}{|c|c|c|c|}
\hline \multirow[b]{2}{*}{ Compound } & \multicolumn{3}{|c|}{$\%$ of total cpm } \\
\hline & $\begin{array}{l}\text { source } \\
\text { leaf }\end{array}$ & $\begin{array}{l}\text { source } \\
\text { petiole }\end{array}$ & $\begin{array}{l}\text { stalk directly } \\
\text { below source }\end{array}$ \\
\hline $\begin{array}{l}\text { Alanine } \\
\text { Malate } \\
\text { Fructose } \\
\text { Glycolate } \\
\text { Glutamate } \\
\text { Serine, glycine } \\
\text { Citrate } \\
\text { Aspartate } \\
\text { 3-phosphoglyceric acid } \\
\text { Hexose monophosphate } \\
\text { Uridine diphosphoglucose } \\
\text { Polymers (origin) } \\
\text { Sucrose } \\
\text { Raffinose. } \\
\text { Stachyose }\end{array}$ & $\begin{array}{r}0.7 \\
2.1 \\
0.6 \\
1.2 \\
0.2 \\
3.4 \\
0.1 \\
3.1 \\
0.6 \\
0.3 \\
0.1 \\
0.1 \\
80.2 \\
3.5 \\
2.9\end{array}$ & $\begin{array}{l}- \\
- \\
- \\
- \\
- \\
- \\
- \\
- \\
- \\
- \\
- \\
- \\
93.4 \\
5.4 \\
1.2\end{array}$ & $\begin{array}{c}- \\
- \\
- \\
- \\
- \\
- \\
- \\
- \\
\overline{-} \\
- \\
- \\
96.2 \\
3.0 \\
0.8\end{array}$ \\
\hline
\end{tabular}

Table 17. Distribution of radioactivity in the bean plant after 1 hour assimilation of $14 \mathrm{CO}_{2}$ by one set of trifoliate leaves

Plant part

Total radioactivity $\mathrm{cpm}$

Source leaf

Source petiole

stalk to next set of bottom leaves

stalk to next set of upper leaves

opposite stalk and petioles

opposite leaves

Top set of leaves on opposite stalk

Bottom set of leaves

Top set of leaves on main stalk

stalk $5 \mathrm{~cm}$ below last set of leaves

$$
\begin{array}{r}
537,500 \\
91,000 \\
76,230 \\
21,475 \\
5,195 \\
3,200 \\
514 \\
24,805 \\
62,220 \\
41,379
\end{array}
$$




\section{a. Materials and methods}

\section{1) Preparation of enzyme extracts}

Freshly harvested cassava roots (cultivar No. 6.8) were washed and placed in an ice bucket. All. subsequent procedures were carried out at $4^{\circ} \mathrm{C}$. The peel was removed and the root macerated into an equal volume of buffer containing $0.1 \mathrm{~N}$ Tris-HCl, $\mathrm{pH} 7.6,0.05 \mathrm{~N}$ B-mercaptoethanol, and $0.001 \mathrm{~N}$ EDTA. This slurry was then homogenized at high speed 4 times at 15 second intervals. The fibrous material was removed by straining through cheese cloth, and the suspension of starch granules collected by centrifugation at $2000 \mathrm{xg}$ for $10 \mathrm{~min}$. The starch granules were suspended in several volumes of buffer and recentrifuged. After this procedure had been repeated four times, the granules were stored as a thick paste for use in enzyme reactions. Part of the washed granules were suspended in 4 volumes of acetone at $-15^{\circ} \mathrm{C}$ and centrifuged at $0^{\circ} \mathrm{C}$. This procedure was repeated three times, then the starch granules were dried in a vacuum. The supernatant from the first centrifugation was recentrifuged at $20,000 \mathrm{xg}$ for $15 \mathrm{~min}$. Proteins were precipitated from the supernatant solution by slow addition of crystalline ammonium sulfate. The precipitates were dissolved in $1 \mathrm{ml}$ of $0.025 \mathrm{~N}$ Tris-HCl buffer, $\mathrm{pH} 7.6$, and desalted by dialysis overnight against two 1 l volumes of 0.25 Tris-HCl, $\mathrm{pH} 7.6,0.01 \mathrm{~N} \mathrm{B-mercaptoethanol,} \mathrm{and} 0.001 \mathrm{~N}$ EDTA. In a typical enzyme preparation precedure the following fractions were obtained:
a) starch granules 
b) $20,000 \mathrm{xg}$ particles

c) $0-20 \%\left(\mathrm{NH}_{4}\right)_{2} \mathrm{SO}_{4}$ precipitate

d) 20-40\% $\left(\mathrm{NH}_{4}\right)_{2} \mathrm{SO}_{4}$ precipitate

e) 40-60\% $\left(\mathrm{NH}_{4}\right)_{2} \mathrm{SO}_{4}$ precipitate

\section{2) Determination of enzymatic activity}

Reactions with soluble enzymes were carried out in thin-walled glass capillaries. In each case only one radioactive substrate (usually 0.01 umole) was reacted in the presence and absence of various co-factors with each enzyme fraction. The quantity of co-factor added was always 1 umole and the total volume of the reaction mixture was $30 \mu l$. The mixtures were incubated for $30 \mathrm{~min}$ at $37^{\circ} \mathrm{C}$, then applied-directly to a sheet of chromatography paper. Two dimensional paper chromatography was carried out and the separated compounds analysed by the methods described in section $B .1$.

Reactions with the starch granules were done in 12 $x 35 \mathrm{~mm}$ test tubes. In turn, each radioactive substrate ( 10 Hl) was added to $0.2 \mathrm{ml}$ of slurried starch granules and incubated, under agitation, for $1 \mathrm{hr}$ at $28^{\circ} \mathrm{C}$. Reactions were stopped by addition of $0.5 \mathrm{ml}$ of $95 \%$ ethanol. The contents of the tube were then transferred to a filtering device which contained $11 / 2$ diameter Whatman No. 1 filter paper. Unreacted radioactivity was removed by washing four times each with $100 \mathrm{ml}$ of $80 \%$ ethanol and $100 \mathrm{ml}$ distilled water. The small circular filter paper was dried and the radioactivity quantitated with a gas-flow G.M. counter. 
b. Sucrose reactions catalyzed by cassava root enzymes When only sucrose-U-14C (394 $\mathrm{mCi} / \mathrm{mmole})$ was incubated with each of the prepared enzyme fractions, there were essentially no detectable reactions. However, when various co-factors were incubated with the radioactive sucrose, several reaction products could be located on the chromatograms. The 20-40\% $\left(\mathrm{NH}_{4}\right)_{2} \mathrm{SO}_{4}$ fraction showed the highest activity and the major products were identified as glucose, fructose, UDP glucose, and hexose monophosphate. In some cases, especially in the presence of ATP and $\mathrm{Mg}^{++}$, there were small amounts of other metabolites formed. The results of the "in vitro" metabolism of radioactive sucrose in the presence of various co-factors is summarized in Table 18. Similar results were obtained with different varieties of cassava as well as different ages of roots. The following conclusiones may be drawn from this data:

1) There is very low invertase activity in the cassava root, i.e. Sucrose $\rightarrow$ glucose + fructose

2) The major pathway for sucrose conversion occurs via the reversible reaction catalyzed by sucrose-UDP glucosyltransferase, i.e. Sucrose + UDP $\rightarrow$ UDP glucose + fructose

3) The presence of nucleotides and metal iones strongly influence the metabolism of sucrose.

4) Both UDP and ADP can serve as the nucleotide acceptor in the glucosyltransferase reaction, however, UDF shows the highest activity and is least affected by the presence of other nucleotides. The comparison of the reactions of UDP+ATP with ADP+UTP are of particular interest in this regard. 
Table 18. Effect of co-factors on the reaction products from radioactive sucrose catalyzed by cassava root enzymes

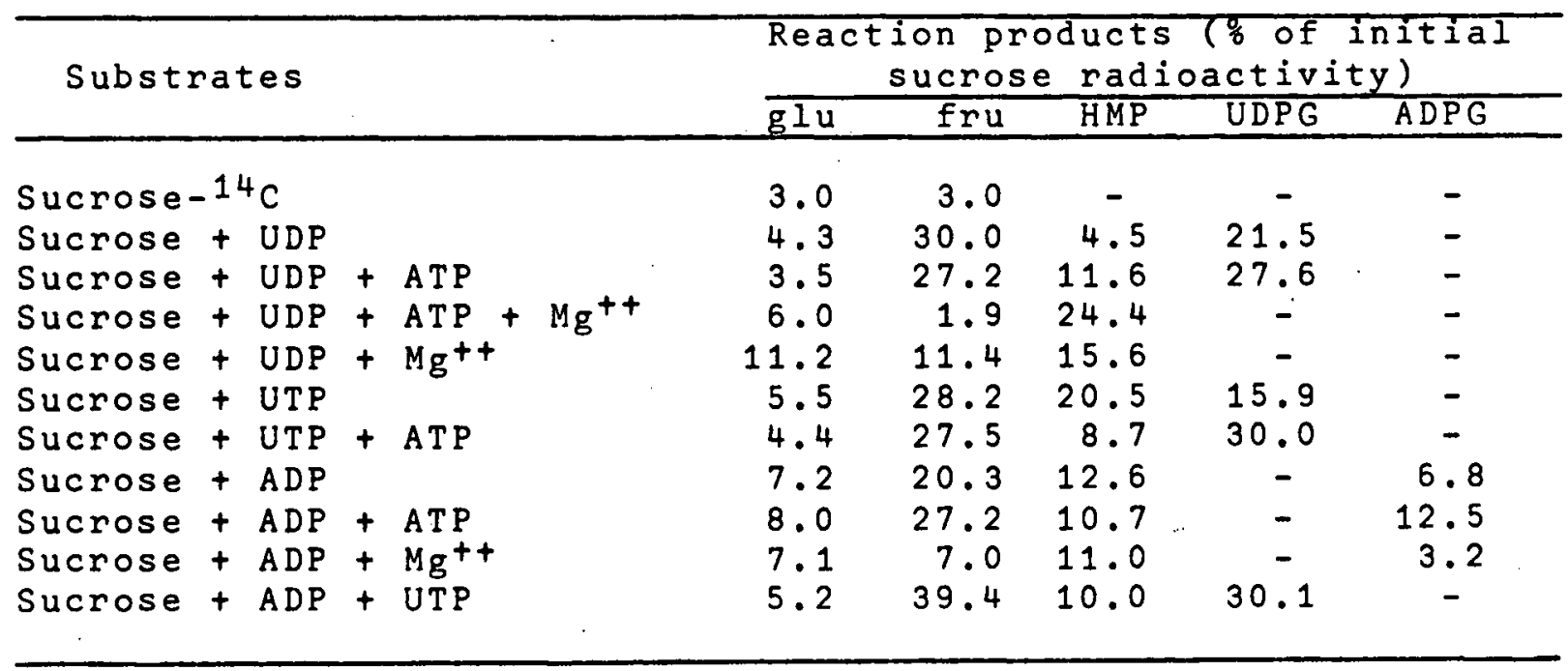

Sucrose-UDP glucosyltransferase has also been shown to have high activity during starch deposition in corn endosperm (Tsai, 1974) and potato tubers (Pressey, 1969). Invertase activity has been reported to be low in potato tubers (Pressey and Shaw, 1961) because of the presence of a protein invertase inhibitor. These authors found that the inhibitor could be selectively denatured by rapid mixing (foaming) of the crude extract, thus allowing the detection of high levels of invertase activity in potato tubers. When these procedures were carried out with the cassava root extracts, the invertase activity still remained very low.

c. Fructose reactions catalyzed by cassava root enzymes Since fructose is one of the products of the sucroseUDP glucosyltransferase reaction it is an important percursor 
root metabolite. In oder to establish its metabolic pathway, fructose-U- ${ }^{14} \mathrm{C}(200 \mathrm{mCi} / \mathrm{mmole})$ was incubated with each of the prepared enzyme fractions. Activity was found mainly in the 20-40\% $\left(\mathrm{NH}_{4}\right)_{2} \mathrm{SO}_{4}$ fraction and only occurred in the presence of ATP and was activated by $\mathrm{Mg}^{++}$ions (Table 19). The reaction products formed in the latter case were diverse; however, small quantities of compounds typically found in the glycolytic and citric acid cycle pathways were identified. Thus it appears that fructose is phosphorylated by a hexokinase reaction, then partly metabolized by glycolytic and respiratory enzymes to supply energy for root development. The enzymes necessary for its conversion to UDP glucose and therefore starch synthesis are also present in the cassava root.

d. Glucose-1-phosphate reactions in the cassava root When glucose-1-phosphate-U- ${ }^{14} \mathrm{C}$ ( $\left.231 \mathrm{mCi} / \mathrm{mmole}\right)$ was incubated with the prepared enzyme fractions, several activities were observed. The highest activities were found to be present in the 20-40\% ( $\left.\mathrm{NH}_{4}\right)_{2} \mathrm{SO}_{4}$ fraction and the starch granules. The activity catalyzed by the starch granules was shown to be starch synthesis and will be discussed in the next section. The activity of the 20-40\% fraction and the effect of added co-factors is shown in Table 20. The most active enzyme was UDP glucose pyrophosphorylase, i.e., glucose-1-phosphate+UTP t+UDP glucose $+\mathrm{PP}_{i}$. In contrast to this there is very low activity of $A D P-$ glucose pyrophosphorylase. The UDP glucose which was formed by this reaction was converted to sucrose via the reverse reaction 
Table 19. Effect of cofactors on the reaction products from radioactive fructose catalyzed by cassava root enzymes

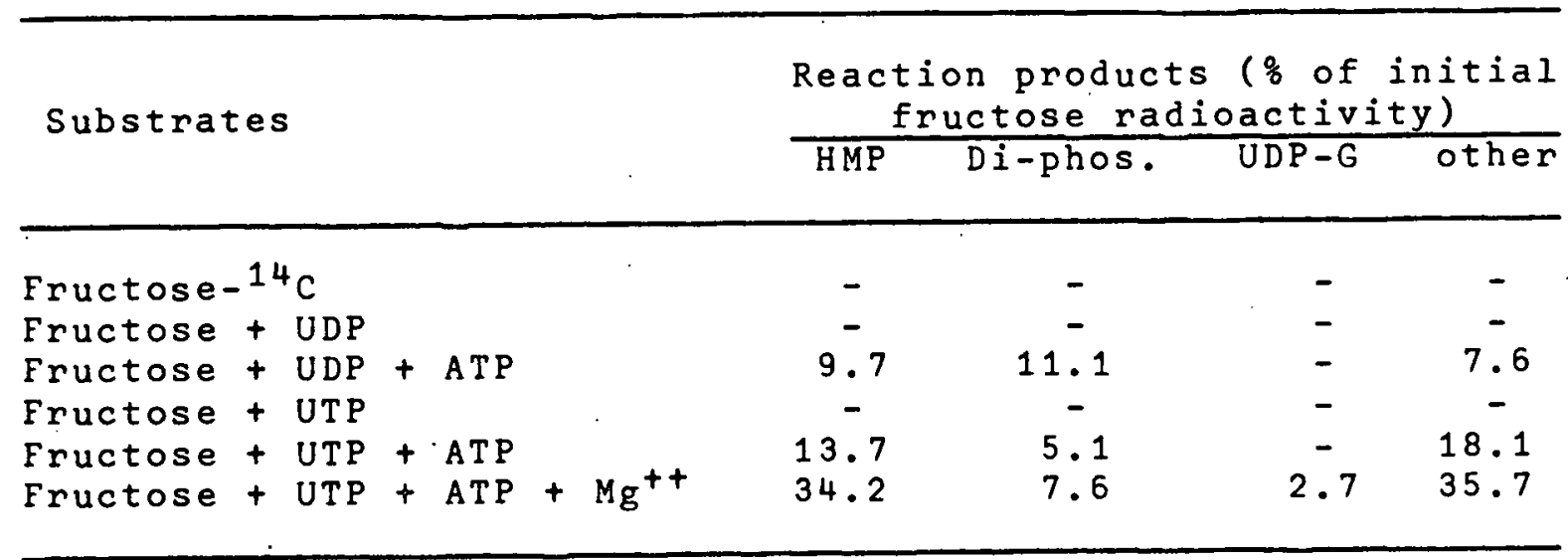

Table 20. Effect of co-factors on the reaction products from radioactive glucose-1-phosphate catalyzed by cassava root enzymes

Substrates

Reaction products ( $\%$ of initial glucose-1-phosphate radioactivity glu fru suc UDPG ADPG other

Glucose-1-phosphate- ${ }^{14} \mathrm{C}$

Glucose-1-phosphate+UTP

$\begin{array}{rrc}36.9 & 12.1 & - \\ 6.7 & 2.0 & 42.7 \\ 8.3 & 4.0 & 56.0 \\ 30.8 & 7.0 & - \\ 3.2 & 31.2 & -\end{array}$

$\begin{array}{ccc}- & - & 34.8 \\ 25.2 & - & 12.8 \\ 4.0 & - & 16.0 \\ - & - & 34.6 \\ - & 4.0 & 72.0\end{array}$

of the sucrose-UDP glucosyltransferase enzyme. Reactions in which radioactive UDP-glucose was the starting substrate gave essentially the same results as for glucose-1-phosphate in the presence of UTP. The $\mathrm{Mg}^{++}$ion appears to have a large.effect on the reversibility of the transferase reaction. 
e. Catalytic activity of starch granules from cassava root Cassava starch granules were prepared and reactions carried out as described in the methods section. Radioactive glucose, sucrose, glucose-6-phosphate, glucose-1-phosphate, and UDP-glucose were each incubated. with the starch granules for 1 hr. As shown in Table 21, the starch granules contain bound starch phosphorylase and starch synthetase enzymes. Starch phosphorylase catalyzes the reversible conversion of glucose-1phosphate to starch, while starch synthetase catalyzes the irreversible synthesis of starch from UDP glucose. Both of these activities were lost when the granules were disrupted. When treated with acetone the phosphorylase activity is denatured while that of starch synthetase remains active. Starch granules from other sources, such as corn, potato, rice, and beans, have also been shown to contain these bound enzymes (Leloir, 1960).

Table 21. Catalytic activity of cassava starch granules

\begin{tabular}{lcc}
\hline Radioactive compound & $\begin{array}{l}\text { Starch synthesis }(\% \text { conversion }) \\
\text { no acetone } \\
\text { treatment }\end{array}$ & $\begin{array}{c}\text { acetone } \\
\text { treatment }\end{array}$ \\
\hline Glucose & 3 & $<0.1$ \\
Sucrose & 2 & $<0.1$ \\
Glucose-6-phosphate & 8 & $<0.1$ \\
Glucose-1-phosphate & 43 & 2 \\
UDP glucose & 36 & 20 \\
\hline
\end{tabular}


f. Enzymatic activities present in the starchy tissue of the cassava seed stalk

Soluble enzymes were prepared from the soft, outer tissue of the seed stalk of 2 month old cassava plants. When the enzyme fractions were incubated with radioactive glucose-1phosphate and sucrose basically two reactions occurred (Table 22 ). UDP glucose pyrophosphrylase was detected in both the 0-20 and 20-50\% $\left(\mathrm{NH}_{4}\right)_{2} \mathrm{SO}_{4}$ fractions while sucrose-UDP glucosyltransferase was only active in the latter. Both enzymes appear to have a high specificity for the uridine nucleotides. These results demonstrate that the seed stalk of the young cassava plant contain the necessary enzymes for conversion of sucrose to starch.

Table 22. Catalytic activity of cassava seed stalk enzymes

\begin{tabular}{lc}
\hline Radioactive compound & $\begin{array}{c}\text { Product as } \% \text { of initial radioac- } \\
\text { tivity }\end{array}$ \\
\cline { 2 - 3 } glu fru suc HMP UDPG ADPG
\end{tabular}

I. $0-20 \%$ ammonium sulfate fraction

sucrose

sucrose+UDP

sucrose+ATP

glucose-1-phosphate

glucose-1-phosphate+ATP+Mg++

glucose-1-phosphate+UTP+Mg ++

II. 20-50\% ammonium sulfate fraction

$\begin{array}{lrrrrrr}\text { sucrose } & - & - & - & - & - & - \\ \text { sucrose+UDP } & 6.1 & 29.1 & - & 12.8 & 34.6 & - \\ \text { sucrose+ATP } & - & - & - & - & - & - \\ \text { Glucose-1-phosphate } & 19.3 & 17.2 & - & - & - & - \\ \text { glucose-1-phosphate+ATP+Mg++ } & 7.4 & 10.3 & - & - & - & - \\ \text { glucose-1-phosphate+UTP+Mg++ } & 21.3 & 24.6 & 20.7 & - & 22.3 & -\end{array}$


4. Summary of biochemical characteristics of cassava

a. The reductive pentose phosphate pathway ( $C_{3}$ metabolism) is the major photosynthetic pathway in cassava.

b. Cassava leaves appear to have a high rate of photorespiration.

c. During active photosynthesis the leaves produce a large excess of sucrose.

d. Sucrose is the translocated photosynthetic product, and translocation occurs from source to sink in essentially a unidirectional manner.

e. Sucrose is cleaved to fructose and UDP glucose in the root by the enzyme sucrose-UDP glucosyltransferase.

f. Invertase appears not to be active in the cassava root.

g. UDP glucose is the major precursor for starch synthesis.

h. The nucleotide balance and metal ions appear to be most important in regulating the activity of the sucrose-UDP glucosyltransferase reaction.

i. The young seed stalk serves as a storage organ prior to root enlargement, and contains the complete enzyme system for starch synthesis.

j. See Fig. 6 for diagram of sucrose metabolism in the cassava root. 
54

Fig. 6. Schematic diagram of sucrose conversion in the cassava root.

Sucrose

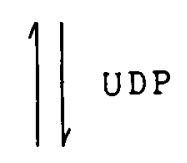

fructose
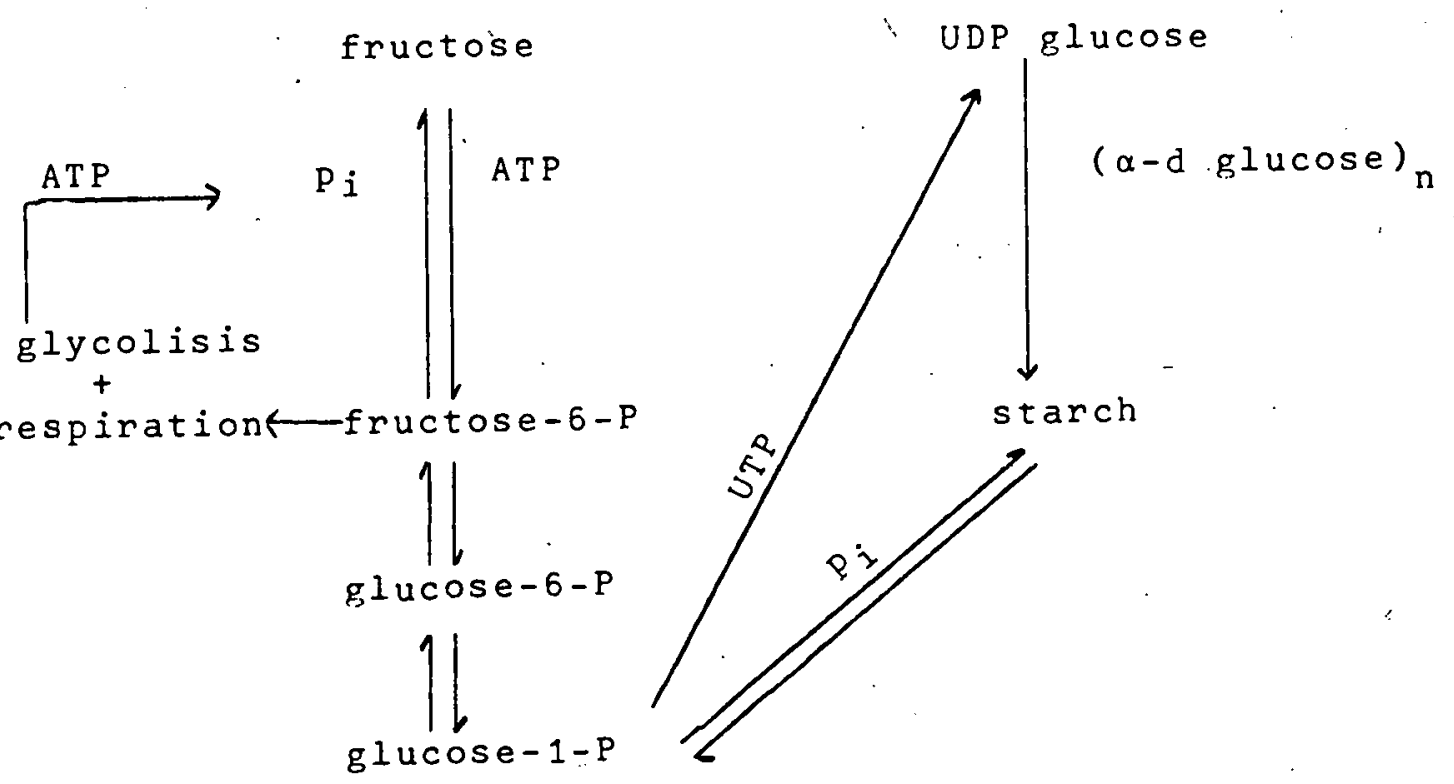


\section{References}

Bassham, J.A. and M. Calvin. 1957. The path of carbon in photosynthesis. Englewood Cliffs, N. J., Prentice-Hall.

Bjorkman, 0. and J. Berry. 1973. High-efficiency photosynthesis. Scientific American 229:80-94.

Chopowick, R. E. and D. F. Forward. 1974. Translocation of radioactive carbon after the application of $14 \mathrm{C}-a$ anine and $14 \mathrm{CO}_{2}$ to sunflower leaves. Plant Physiol. 53:21-27.

Coursey, D. G. and P. H. Haynes. 1970. Root crops and their potential as food in the tropics. World Crops July/ August:261-265.

Leloir, L. F., M. A. Rongine De Fekete and C. C. Cardini. 1961. Starch and oligosaccharide synthesis from uridine diphosphate glucose. Jour. Biol. Chem. 236:636-641.

Pressey, R. 1969. Potato sucrose synthetase: purification, properties, and changes in activity associated with maturation. Plant Physiol. 44:759-764.

Pressey, R. and Shaw, R. 1966. Effect of temperature on invertase, invertase inhibitor, and sugars in potato tubers. Plant Physiol. 41:1657-1661.

Tasi, C. Y. 1974. Sucrose-UDP glucosyltransferase of Zea mays endosperm. Phytochemistry 13:885-889.

Zelitch, I. 1971. Photosynthesis, photorespiration, and plant productivity. New York, Academic Press.

\section{COLLECTION OF RAINFALL FOR FALLOUT ANALYSIS}

Since August, 1959 , in cooperation with the Health and Safety Laboratory (HASL) of the U.S. Atomic Energy Commission, monthly fallout collections by using ion-exchange columns, have been carried out at Turrialba. The resin columns and the monthly rainfall records are sent to HASL for radiochemical analysis. This cooperation is expected to continue. 
II. PLANS FOR THE CONTINUATION OF OBJECTIVES AND POSSIBLE NEW OBJECTIVES IN CONSIDERATION OF PAST RESULTS

\section{A. Induced Mutations and Plant Improvement}

1. Cassava (Manihot esculenta)

As indicated in the above research report, cassava is a basic staple food in the lowland tropics and forms a principal crop in the multiple cropping system. In order to operate this system more efficiently, certain phenotypes of cassava plants are necessary. One of the types is erect and compact growth. During the past year, this type of mutant has been induced by pollen irradiation. The mutant will be propagated, subject to yield-trial, and the released.

In the coming years, research on cassava will be mostly emphasized on acyanogenesis. Since a cassava cultivar free of the cyanogenic glucosides has not been found in the natural population, induced mutation may be an alternative method for the improvement. As has been indicated in the annual progress report (1975), several methods of approach have been taken in our program for acyanogenesis: a) pollen irradiation, b) somatic mutation induction, and e) haploid breeding.

a) Pollen irradiation. The research in this direction is well under way. Since last year, more than $2000 \mathrm{R}_{1}$ plants were obtained from pollen irradiation with various doses of gamma radiation, and more $R_{1}$ plants are expected to be obtained this year. About half of these $R_{1}$ plants have been screened using the peel of the root as an assay. This screening 
experiment will be continued.

$$
\text { A few } R_{1} \text { plants with a low HCN grading (No. } 3 \text { ) in }
$$

the Guignard test have been isolated. These selected plants will be propagated in a separate field plot and will be used for selfing in order to obtain a large population of the $R_{2}$ progenies for further screening. Should the production of cyanogenic glucosides be determined by quantitative genetic factors, plants with lower HCN content would be expected to be obtained in the selfed $R_{2}$ generation.

b) Somatic mutation induction. At present, more than 800 irradiated cassava cuttings have been grown in the field, and the purification of the chimeric sectors will be carried out by vegetatively propagating the plants to the second or third generations. By that time, it is expected to have 4 to 5 thousand progenies for screening.

c) Haploid breeding. The advantages of using haploids in plant breeding have long been known, but the basic problem is that a haploid is not always available in a plant species. In the past year, an attempt was made to develop a haploid cassava plant by the anther culture method. As was stated in the research section of this triennial report, the culture medium and the conditions for the callus development from the anther have been worked out. Studies will be continued to 1) identify the chromosome number of the callus to see whether it is a haploid number, and 2) investigate the medium requirements for shoot and root differentiation. 
2. The common bean (Phaseolus vulgaris)

The work on seed-coat color improvement in beans using induced mutation method has been well established in our Program. We feel that for improving the seed-coat color from black to white, mutation breeding is by far more efficient than the conventional hybridization method. Usually, the desirable white mutant can be obtained in the $R_{2}$ or $R_{3}$ generation. The induced white mutants, especially the NEP-2, have been propagated in quantity for distribution. The work which remains to. be done is to introduce this mutant into more bean growing areas, although we have distributed the seeds to 20 different countries. Because of the food shortage in recent years, the improvement of food crops has been emphasized not only in quantity but in quality. This year, we have initiated the research on the nutritional improvement of food legumes. Since the common bean is a staple food crop and a major protein resource in the American tropics, a quantitative or qualitative improvement of the protein in this species would be of great value for many developing countries.

The use of induced mutation method as a tool in plant breeding has been a controversial matter for some time. Since most of the induced mutations are deleterious, it thus frequently is considered as an unsuccessful tool for plant breeding. In the case of protein improvement in food crops, successful results have been obtained by the Danish AEC group in barley. We also have recently obtained encouraging results 
while screening the seed-coat color mutants of beans. Mutagenic treatment of the bean seeds from a variety, Turrialba-4, has been performed. The $R_{2}$ progenies will be harvested and will be screened for protein content this year.

\section{B. Photosynthetic Efficiency and Plant Productivity Due to the high yield of essentially pure starch in} the cassava root, we are using it as a model system for the study of how plants regulate the flow of photosynthate into one storage product rather than another. In the past year, by use of radioactive tracer methods, we have established the photosynthetic pathway from $\mathrm{CO}_{2}$ fixation in the leaf to starch synthesis in the root. Cassava fixes $\mathrm{CO}_{2}$ predominantly by the reductive pentose phosphate pathway with sucrose as the major end product in the leaf. The sucrose is then translocated in an unidirectional manner directly to the root where it is first converted to fructose and uridine diphosphoglucose. The uridine diphosphoglucose serves as a direct precursor for starch synthesis while fructose is mainly metabolized for production of energy.

For the coming years, plans for this project will

include: 1) quantitative measurement of photosynthetic and photorespiratory rates under a variety of conditions, as well as at various stages of development of the cassava plant;

2) quantitative measurements of translocation rates under a variety of conditions; 3 ) establish the rate limiting 
enzymatic step of starch synthesis in the root and study its regulatory properties; 4) establish what metabolic factors in the root have an effect on net photosynthetic rate, i.e., what effect would an inhibition of sucrose-UDP glucosyltransferase have on the photosynthetic rate? 
III. GRADUATE STUDENTS TRAINED, AND DEGREE GRANTED

Name Nationality $\begin{array}{r}\text { Degree Period Trained } \\ \text { Granted }\end{array}$

\begin{tabular}{|c|c|c|c|c|c|}
\hline DEL POZO, Jorge 1 & Peru & M.S. & Sept. & $1971-0 \mathrm{ct}$. & 1973 \\
\hline GUTIERREZ, Evelyn B. $\mathrm{de}^{2}$ & Guatemala & & July & $1973-\mathrm{Jan}$ & 1974 \\
\hline ICAZA, Javier ${ }^{3}$ & Nicaragua & M.S. & April & 1971-Jan. & 1974 \\
\hline OPEZ, Ma. Eugenia M. $\mathrm{de}^{4}$ & Costa Rica & & Nov. & $1973-\mathrm{DeC}$. & 1974 \\
\hline SAMANIEGO, Alfredo 1 & Ecuador & M.S. & oct. & $1971-J u n e$ & 1973 \\
\hline SULMANN, Augusto 5 & Brazil & & Sept. & $1972-F e b$. & 15 \\
\hline
\end{tabular}

1. On Dutch Government Fellowship.

2. Special student from the University of San Carlos, Guatemala, doing her thesis work on Insect Pathology.

3. On IICA Northern Zone Fellowship.

4. Staff from the University of Costa Rica, doing her thesis work on Radiation Effects in Beans.

5. Special student sponsored by the International Atomic Energy Agency for special training. 
IV. BIBLIOGRAPHY

Gonzalez, S., Igue, K. and Besoain, E. Secuencia de meteorización y. su relación con las propiedades de carga y superficie de la fracción arcilla de algunos andosoles de costa Rica. Turrialba 22(4):439-448. 1972 .

Guerra Chomon, J. C., Moh, C. C, and Alan, J. J. Inducción de mutaciones de color de semilia con metanosulfonato de etilo en algunas variedades de frijol común. Turrialba (in press).

Hidalgo-Salvatierra, 0 . Book review of: United States Academy of Sciences. Biochemical interactions among plants. Washington, D. C., National Academy of Sciences, National Research Council, 1971. 134 p. Turrialba 22(2):229. 1972.

and Berrios, F. Studies on the shootborer Hypsipyla grandella Zeller. XI. Growth of larvae reared on a synthetic diet. Turrialba 22(4):431-434. 1972.

and Berrios, F. Studies on the shootborer Hypsipyla grandella Zeller. XII. Determination of the L $C_{50}$ of Metarrhizium anisopliae (Metchnikoff) Sorokin spores on fifth instar larvae. Turrialba 22(4):435-438. 1972.

and Palm, J. D. Studies on the shootborer Hypsipyla grandella Zelier. XIII. Susceptibility of first instar larvae to Bacillus thuringiensis. Turrialba 22(4):467-468. 1972 .

and Lawrence, J. S. Book review of: Talbot, P.H.B. Principes of fungal taxonomy. London, MacMillan, 1970 . 274 p. Turrialba 22(4):474-475. 1973.

Jaramillo, R., Jimenez, F. and Hidalgo, 0 . Susceptibilidad de las larvas de Sibine apicalis (Dyar) a Bacillus thuringiensis var. kurstaki. Turrialba 24(1):106-107. 1974.

Katiyar, K. P. Insemination capacity of gamma sterilized Mediterranean fruit fly males irradiated during pupal stage. Turrialba 23(1): 48-51. 1973 .

- Mating competitiveness and rate of sexual maturity of gamma-sterile medfly males. Túrrialba 23(2):216-221. 1973 .

and Ramirez, E. Sperm transferability of gamma-sterilized Mediterranean fruit fly males. Turrialba 23(3):324-326. 1973. 
Katiyar, K. P. and Ramirez, E. Mating duration of gamma irradiated Mediterranean fruit fly males. Turrialba 23(4):

471-472. 1973 .

Lawrence, J. S. and Hidalgo, O. Book review of: Western, J. H., ed. Diseases of crop plants. London, Macmillan, 1971.404 . Turrialba 22(4):472. 1972.

Miranda, E. R., Igue, K and Paez, G. Efeito de cultivos sucessivos na relaçao $Q / I$ de potásio. Revista Theobroma 2(4):8-15. 1972 .

and Igue, K. Quantidade/Intensidade de potássio em solos da regiao cacaueira da Bahia. Revista Theobroma 2(3):47-55. 1972 .

Moh, C. C. Induced mutations in coffee. In Mutation Breeding of Vegetatively Propagated and Perennial Crops. Proceedings. IAEA, Vienna, 1972. Vienna, IAEA, 1973. pp. 129-136.

and Alan, J. J. Methods for inducing mutations in cassava and the possible uses of the mutants. In Mutation breeding of vegetatively propagated and perennial crops. Proceedings, IAEA, Vienna, 1972. Vienna; IAEA, 1973. PP. 67-74.

and Alan, J. J. The use of Guignard test for screening cassava cultivars of low hydrocyanic acid content. In Tropical Root and Tuber Crops Newsletter, No. 6, $197 \overline{3 .}$ Puerto Rico, International Society for Tropical Root Crops, 1973. pp. 29-30.

and Alan, J.J. Radiosensitivity of some tropical plant species. Turrialba (24(2):156-159. 1974.

Induction of anther callus in cassava. 1975. (Submitted for publication in Tropical Root and Tuber Crops Newletter).

Morales, C. and Greene, G. L. Growth inhibitors in a radiation induced dwarf bean mutant. Turrialba 22(2):168-172. 1972 .

Samaniego, A. and Katiyar, K. Estudio sobre el barrenador Hypsipyla grandella (Zelier)(Lep.: Pyralidae). XXIII. Efectos de radiación gamma en larvas, pupas y adultos. Turrialba 24(1):95-99. 1974 .

Suarez, D. and Igue, K. Effectoof granule size on phosphate efficiency in volcanic soils. To be submitted to SSSAP. and Igue, K. Efecto del tamaño de granos en la absorción de fosforo en suelos volcánicos. Turrialba 24(2):180186. 1974 . 
V. OPINION AS TO THE PRESENT STATE OF KNOWLEDGE IN THIS AREA OF RESEARCH, ITS SIGNIFICANCE. IN THE FIELD OF BIOLOGY AND MEDICINE AND NEEDED FUTURE INVESTIGATIONS

A. Mutation Breeding and Plant Improvement In a triennial report to the USAEC (1969-1972 Triennial report, (00-3217-05), we quoted statistics projecting that there would be six billion people living on earth by the end of this century. A supply many times greater of protein will be needed in order to keep the human race at a reasonable nutritional level. During the past years, the problem of food shortage occurred earlier than we expected, especially in the developing countries. The lines of research covered by the Nuclear Energy Program are of an agricultural nature with a major objective of improving agricultural crops for human consumption.

The two food crops, cassava and the common bean, chosen for the improvement in the program are of utmost importance in the tropics. Cassava has a large root production and serves as an energy source (carbohydrates) to more than 200 million people in the tropics. The common bean has been traditionally used as a major protein source in many developing countries.

A number of food plants containing certain natural chemical constituents are toxic for human consumption. The cyanogenic glucosides in cassava and the hemagglutinins in the legumes are good examples. Because of the large consumption of cassava roots (in tropical Africa, an individual consumes as much as one kilogram per day), concern has arisen as to the possible poison 
effect due to hydrocyanic acid $(\mathrm{HCN})$. It has been speculated that tropical ataxic neuropathy in West Africa may be a manifestation of chronic cassava poisoning. The basic answer to this problem is to cultivate a cassava variety free of the cyanogenic glucosides.

In Nigeria, a breeding program for cassava free of $\mathrm{HCN}$ has been carried out for some time by the International Institute of Tropical Agriculture. Almost 89000 cassava plants were screened and no HCN-free plants were found. It appears that the possibility of finding $\mathrm{HCN}$-free plants in the germ plasm collection was exhausted. Thus, induced mutation would be an alternative method for acyanogenesis in cassava.

The needs for nutritional improvement in food legumes need little stress. In recent years, the yields of food legumes, in fact, have gone down. The reason for this, no doubt, has been due to the lack of new high-yielding varieties or the lack of improved technique for the improvement. Moreover, certain legumes such as beans, lack the essential sulfur-containing amino acids in their proteins. The deficiency of s-amino acids gives low protein efficiency. All these need to be improved.

Protein improvement by induced mutant method has been successful in barley. A 45 percent increase in lysine has been found in several mutants of barley by the Danish scientists. In our preliminary investigations, we have recently found a bean mutant high in total crude proteins. These results certainly demonstrate the possibility of using induced mutation method for nutritional improvement in plants. 
B. Biochemical and Physiological Properties of Cassava

As has been described in earlier reports of the Nuclear Energy Program, one of the most attractive characteristics of cassava is its very high yield of roots. Since the root contains about $63 \%$ water and $35 \%$ carbohydrate, this represents a high production of essentially pure carbohydrate that is predominantly starch. This high efficiency of starch production suggests the cassava plant to be an ideal material for the study of photosynthetic metabolism, especially as it relates to net productivity and yield.

Although all leaves from early development until time" of senescence carry out photosynthetic carbon fixation via the reductive pentose phosphate cycle, the flow of carbon from the cycle into various other biosynthetic pathways varies with age. The plant regulates, by some unknown mechanism(s), the direction of flow to suit its need for growth. At some point in their development, all leaves become net exporters of photosynthate and translocate carbon, usually as sucrose, toother plant parts where it is normally stored as polymers. At this stage in development, the leaf must receive a regulatory signal to suppress the synthesis of lipids and proteins, while activating the flow to carbohydrates (sucrose). Clearly the efficiency of this regulatory process could be critical for net productivity. Those plants better able to suppress ail except sucrose synthesis may continue to photosynthetize at rapid rates, while others unable to do so could suffer a decreased rate of carbon fixation. An 
efficient mechanism for sucrose translocation would be equally important at this point. Regulation. of photosynthetic metabolism, as described above has not been studied to any extent in green plants. Almost all research in this area has been carried out with green alga or isolated chloroplasts. Studies directed towards an understanding of these regulatory mechanisms in higher plants should be worthwhile.

Very little work has been done on the biochemical and physiological basis of cassava's high productivity. In the past year we have established some fundamental characteristics of photosynthesis, translocation, and starch biosynthesis in this plant. At this time, however, we still don't know what its high productivity is due to. Some of the possibilities are that it has: 1) a more efficient fixation process than other $C_{3}$ plants; 2) an ability to decrease its rate of photorespiration or has a lower rate than most $c_{3}$ plants; 3 ) an increased efficiency of sucrose transport from the leaf; or 4) some other unknown regulatory mechanism which stimulates carbohydrate metabolism. A continuation of the analysis of the basic biochemical processes of the cassava plant will hopefully lead to a better understanding of plant productivity. Clearly a knowledge of the fundamental plant processes which cause plant productivity and yield would have a huge impact for agriculture. This could provide a means of biochemically manipulating plants to better suit man's food and material needs. 
VI. THE PRESENT DIVISION OF FEDERAL SUPPORT FOR THE PROGRAM

The research and training activities in the Nuclear Energy Program at the Tropical Agricultural Research and Training Center are 100 percent support by the U. S. Energy Research and Development Administration under Contract AT(11-1)-2505. 